\title{
The level of risk, effects response to potential health emergencies, prevention and control method of COVID-19: A systematic review
}

\author{
Addis Adera Gebru ${ }^{\mathrm{j}, 1, \mathrm{~m}, *}$, Tadesse Birhanu ${ }^{\mathrm{b}}$, Eshetu Wendimu ${ }^{\mathrm{c}}$, Agumas Fentahun Ayalew $^{\mathrm{n}}$, \\ Selamawit Mulat ${ }^{\mathrm{d}}$, Hussen Zakir Abasimel ${ }^{\mathrm{e}}$, Ali Kazemi ${ }^{\mathrm{f}}$, Bosenu Abera Tadesse ${ }^{\mathrm{g}}$, \\ Beniam Adera Gebru ${ }^{\mathrm{h}}$, Berhanu Senbeta Deriba ${ }^{\mathrm{a}}$, Nigus Shimelis Zeleke ${ }^{\mathrm{i}}$, Abebe Gule Girma ${ }^{\mathrm{b}}$, \\ Bulgantsetseg Munkhbat ${ }^{\mathrm{b}}$, Qamar Kassim Yusuf ${ }^{\mathrm{k}}$, Amana Ogeto Luke ${ }^{\mathrm{l}}$ and Dejene Hailu ${ }^{\mathrm{o}}$ \\ ${ }^{a}$ Department of Public Health, College of Health Sciences, Salale University, Fitche, Ethiopia \\ ${ }^{\mathrm{b}}$ Department of Animal Sciences (Specialist on Infectious Diseases), College of Agriculture and Natural Resources, \\ Salale University, Fitche, Ethiopia \\ ${ }^{\mathrm{c}}$ Research and Community Services Vice President, Salale University, Fitche, Ethiopia \\ ${ }^{\mathrm{d}}$ Injibara Woreda Health Office, Regulatory Officer, Injibara, Ethiopia \\ ${ }^{\mathrm{e}}$ Department of Midwifery, College of Health Sciences, Salale University, Fitche, Ethiopia \\ ${ }_{\mathrm{f}}^{\mathrm{f}}$ Department of Health Economics, School of Public Health, Research Center for Environmental Determinants of \\ Health, Kermanshah University of Medical Sciences, Kermanshah, Iran \\ ${ }^{\mathrm{g}}$ Department of Animal Sciences, College of Agriculture and Natural Resources, Salale University, Fitche, Ethiopia \\ ${ }^{\mathrm{h}}$ Addis Ababa City Adminstration Public Procurement and Materials, Addis Ababa, Ethiopia \\ ${ }^{i}$ Department of Sociology, College of Social Sciences and Humanities, Salale University, Fitche, Ethiopia \\ ${ }^{\mathrm{j}}$ International Relation Directorate Director, Salale University, Fitche, Ethiopia \\ ${ }^{\mathrm{k}}$ Northern Counties Community Empowerment, Garissa, Kenya \\ ${ }^{1}$ Department of Public Health, Reft Valley University, College of Health Sciences, Abichu Campus, Addis Ababa, \\ Ethiopia \\ ${ }^{\mathrm{m}}$ Department of Public Health, College of Health Sciences, Kotebe Metropolitan University, Addis Ababa, Ethiopia \\ ${ }^{\mathrm{n}}$ Department of Public Health, College of Health Sciences, Woldia University, Woldia, Ethiopia \\ ${ }^{\circ}$ Department of Nursing, College of Health Sciences, Salale University, Fitche, Ethiopia
}

\begin{abstract}
.
BACKGROUND: COVID-19 is currently the major public health burden in the world, with disease and death in the global community from COVID-19 increasing rapidly from time to time worldwide. However, there has been a lack of well-organized information about the level of risk, effects, prevention and control methods of the disease. Therefore the aim of this study is to identify and review a published level of risk, effects response to potential health emergencies, prevention, and control methods of COVID-19 at a global level.

METHOD: A systematic review was performed after literatures were identified by searching the following online databases: medRxiv, Google scholar, PubMed, MEDLINE, EMBASE, and the Cochrane Library with supplementary hand searching of conferences. The online databases contain archives of most English biomedical journals. Scientific papers published online by the Center for Disease Control and the World Health Organization were also included for this analysis. The scientific publications from 01 December, 2019 to 13 April 2020 were included. The 'COVID-19', '2019 novel coronavirus', '2019-nCoV', 'novel coronavirus', and 'Pneumonia' key search terms were used for this review.
\end{abstract}

*Corresponding author: Addis Adera Gebru, Directorate of Director for International Relation and partnership, Department of Public Health, College of Health Sciences, Salale University, Fitche, Salale,
Ethiopia. Tel.: +251984811393; E-mail: addisaderagebru@gmail. com; addis_adera@slu.edu.et; international_relation@slu.edu.et. 
RESULTS: Twenty articles published in reputable journals met the inclusion criteria, representing 20 articles analyses. Of these, $11(55 \%)$ were from China and $3(15 \%)$ from the USA. All 20 were statistical analyses of individual patient data, while 33 used decision-analytic modeling. The overall structures were most commonly described as being Markov $(n=27)$ but, the methods were heterogeneous. The World Health Organization (WHO) reported that most frequently world communities including healthcare providers were 'alive' or 'dead', with COVID-19 related outcomes such as hospitalization and other enclosed action of class distribution most commonly considered as a partition of the 'alive' state. Different approaches to modeling the effects of COVID-91 prevention and control interventions on mortality were used; treatment effects were applied to cardiovascular mortality and all-cause mortality in nine and 20 studies (among the 33 decision-analytic models), respectively. Across included studies, the time horizon ranged from within-trial to lifetime. Outcomes were frequently sensitive to baseline risks of mortality and hospitalization, the relative efficacy of interventions, and unit costs of interventions.

CONCLUSION: The findings from the identified literature showed that the morbidity and mortality rate, including urgent hospitalization, was increasing from day to day. Therefore, all countries should implement COVID-19 prevention and control programes. Moreover; urgent global collaboration is needed to design effective prevention and control strategies as soon as possible.

Keywords: Coronavirus disease 2019, Level of risk, Potential health Emergencies, Prevention and Control

\section{Background}

Coronavirus had been observed to cause epidemic diseases since 2003, and it has also caused many community health problems that resulted in globally serious issues. Moreover, these cases consecutively occurred as a severe acute respiratory syndrome (SARS), middle east respiratory syndrome (MERS), and Coronavirus disease 2019 (COVID-19) [1]. There is a new community health problem threatening the globe with the emergence and spread of COVID-19 or the severe acute respiratory syndrome coronavirus 2 (SARS-CoV-2). The virus started in bats and was transmitted to humans through as yet unknown intermediary animals in Wuhan, Hubei province, China in December 2019 [2].

COVID-19 is basically transmitted by respiratory droplets and close contact. Pulmonary function testing procedures have been associated with an increased risk of COVID-19 transmission from clients and health professionals [3]. The changing transmission situations, specifically, nosocomial transmission and spread through mildly symptomatic cases, is a range of concern. There is a range of signs and symptoms from mild to serious disease with major complications such as severe pneumonia, ARDS, acute cardiac injury and septic shock. Bilateral ground-glass opacity and consolidation on imaging with possible clinical features should raise a suspicion about COVID-19. Destitute prognostic regions such as multilobular infiltration on chest imaging, lymphopenia, bacterial co-infection, smoking history, chronic medical conditions like hypertension, and age $>60$ years (MuLBSTA score) [4]. The COVID-19 outbreak that started in Wuhan, Hubei province, China on 31 December, 2019 is now a pandemic with $>100,000$ cases and 3,000 deaths reported in 93 countries as of 07 March 2020. One COVID-19 infection report describes a 64-year-old man who developed rapidly worsening respiratory failure and acute respiratory distress syndrome (ARDS) that required intubation. As the clinical spectrum of COVID-19 ranges widely from mild illness to ARDS with a high risk of mortality, there is a need for more research to identify early markers of disease severity [5].

The Chinese authorities restricted some travel in an attempt to stop the illness from 23 January 2019 and China's financial markets remained closed until Monday 03 February 2019 after authorities extended the Lunar New Year holiday break by three days. The disease then rapidly spread all over the world. The WHO then declared this disease a pandemic on 11 March 2020.

A cluster of patients with pneumonia of unknown cause was linked to a seafood wholesale market in Wuhan, China. A previously unknown betacoronavirus was discovered through the use of unbiased sequencing in samples from patients with pneumonia. Human airway epithelial cells were used to isolate a novel coronavirus, named COVID-19 which formed a clade within the subgenus sarbecovirus, orthocoronavirinae subfamily. Different from both MERS-CoV and COVID-19; SARS-CoV-2 is the seventh member of the family of coronaviruses that infect humans. Enhanced surveillance and further investigation are ongoing (Funded by the National Key Research and Development Program of China and the National Major Project for Control and Prevention of Infectious Disease in China) [6].

Data are lacking on the impact of Middle East Respiratory Syndrome (MERS) on health-related quality of life (HRQoL) among survivors. Functional scores 
were similar for MERS and non-MERS SARI survivors. However, MERS survivors of critical illness reported lower quality of life than survivors of less severe illness. Efforts are needed to address the long-term medical and psychological needs of MERS survivors [7]. The first Chinese data published seem to show that the symptoms in pregnant women are the same as those of the general population. There are no cases of intrauterine maternal-fetal transmission, but cases of newborns infected early suggest that there could be vertical prepartum or neonatal transmission. Induced prematurity and cases of respiratory distress in newborns of infected mothers have been described. Pregnancy is known as a period at higher risk for the consequences of respiratory infections, as for influenza, so it seems important to screen for Covid-19 in the presence of symptoms and to monitor closely pregnant women. In this context of the SARS-Covid-2 epidemic, the societies of gynecologyobstetrics, infectious diseases, and neonatology have proposed a French protocol for the management of possible and proven cases of SARS-Covid- 2 in pregnant women [8].

Predicting the number of new suspected or confirmed cases of COVID-19 is crucial in the prevention and control of the COVID-19 outbreak. Social media search indexes (SMSI) for dry cough, fever, chest distress, coronavirus, and pneumonia were collected from 31 December 2019 to 9 February 2020. The new suspected cases of COVID-19 data were collected from 20 January 2020 to 09 February 2020 [9].

The COVID-19 pandemic is first and foremost a humanitarian crisis. Efforts to contain the virus and support those directly impacted are of utmost importance. The COVID-19 pandemic is an unprecedented global shock that magnifies the impact of inequality, hitting the poor the hardest. In developed countries, frontline workers in the service economy are among the most exposed to the virus and the least able to absorb its financial impact. The hardest hit will be the poor in developing countries, where already-struggling workers will not have the benefit of social safety nets and stimulus packages. The G7 and G20 must immediately help these countries to finance the flattening of the pandemic curve. Longer-term, we must redouble efforts to foster sustainable economic systems, including fair trade and investment [10].

Awareness and attentiveness have implications for the acceptance and adoption of disease prevention and control measures. Social media posts provide a record of the public's attention to an outbreak [11]. The effect of corona discharge-generated air ions on the fil- tration of aerosolized bacteriophage MS2 was studied. A carbon-fiber ionizer was installed upstream of a medium-efficiency air filter to generate air ions, which were used to charge the virus aerosols and increase their filtration efficiency. After the virus aerosols were captured by the filter for a certain time interval, they were exposed to a new incoming air ion flow [12].

The emergency that the world faces today demands that we develop urgent and effective measures to protect people at high risk of transmission. WHO has accelerated research in diagnostics, vaccines, and therapeutics for this novel Coronavirus [13]. The aim of this review study is to identify and review a published level of risk, effects response to potential health emergencies, prevention, and control method of the COVID-2019 outbreak. This review will serve to provide well-organized information for the global community in this regard.

\section{Method}

The method was used to asses level of risk, effects response to potential health emergencies, prevention, and control method of Coronavirus disease 19 from published and unpublished works worldwide. The following procedures are used in this review; choosing appropriate research objective and search strategies; collecting important articles; choosing research articles; extracting and recording of data; finally, summarization, discussion, analyzing, and reporting the results were conducted.

\section{Literature search strategies}

A systematic review was performed after literatures were identified by searching the following online databases: medRxiv, Google scholar, PubMed, MEDLINE, EMBASE, and the Cochrane Library with supplementary hand searching for conferences. The online databases contain archives of most English biomedical journals. Additionally, Scientific papers published online by the Center for Disease Control and the WHO and reputable organizational recognized websites from health sectors and other related sectors and /organizations were included.

This strategy was utilized to decide the precision of the results by comparing them within the related articles from different reputable and key important sources. The review is based on peer-reviewed journal articles on "level of risk, to potential health emergencies, "effects 
response to potential health emergencies, and prevention and control methods" that were published from 31 December 2019 to 20 April 2020. This time span was chosen because the current diseases outbreak and its upto-date information is important to justify and address the objective of the review articles. The 'COVID-19', '2019 novel coronavirus', '2019-nCoV', 'novel coronavirus, and 'Pneumonia' key search terms were used in this review.

Firstly, all searched articles using inclusive criteria were assessed, then after assessing all titles and content of the articles, the value of the articles to address the aim of this study was assumed, and examined. The terms used for searching related articles were "potential health" "emergencies", "prevention", "control", "Coronavirus-2019" pandemic diseases", "viral infections". Also "risk and effect response" and "emergency preparedness" were used together to search the articles from different key relevant databases and official governmental and nongovernmental websites including reports.

The investigators have used the Effective Public Health Practice Project Quality Assessment Tool (EPHPP) (EPHPP, 2020) to assess the quality of quantitative research in this review. This instrument had ordinal scoring for the following components: selection bias, study design, confounders, blinding, data collection methods, withdrawals and dropouts. It helps to assess review study quality and develop recommendations for study results. Each component was rated strong, moderate, or weak, and these ratings were also combined into a global quality rating (strong, moderate, or weak). Two reviewers assessed the quality, and discrepancies were resolved by discussion.

\subsection{Inclusion and exclusion criteria}

The research team read the titles and decided to include articles in the review regarding the following criteria: the study included relevant key instruments to collect raw data including media and other information on the level of risk and effects response to potential health emergencies, prevention, and control method of COVID- 2019 outbreak inclusion of only Novel COVID-19; SARS-CoV-2 outbreak which is currently critically and life-threatening cause of the pandemic disease globally. All articles that were published between 01 December 2019 and 13 April 2020, and those published in English were eligible for the analysis.

From those searched studies that didn't meet these criteria were excluded. This review is focused on the level and/or extent of emergency response for slow COVID-19 transmission, the effects of response to potential health emergencies towards COVID-19 and how to prevent, and control COVID-19. Furthermore, the review identified the main characteristics of COVID-19, effects of emergency preparedness and prevention, and control by hand washing using soap and sanitizer, isolation, quarantine, far from infected and suspected persons, and emergency contact with healthcare provider if there are any symptoms of COVID-19. All abstracts were excluded from this review article. For instance, articles about the impact of a severe acute respiratory syndrome (SARS) care on the general health status of healthcare workers, Middle East Respiratory Syndrome (MERS), and other than directly related to the COVID19 outbreak were excluded from this review.

\subsection{Data collection and analysis}

After the literature search, articles were screened independently by two reviewers for eligibility. A third reviewer was consulted to resolve disagreements. We included studies published in English. Two reviewers had independently reviewed the titles, authors, published year, and abstracts against eligibility criteria.

\subsection{Prisma flow diagram}

The research team has searched a total of 132 articles. The titles, summary or abstract, and the whole body of each article were then checked for their relevance and suitability to be included in the analyses. Finally, a total of 20 articles were found to be eligible [Fig. 1].

\section{Results}

From the total of 20 reviewed studies, 11 (55\%) were conducted potential health emergency, prevention, and control methods of COVID-19 outbreak COVID-19 in China in 2020. This indicated that almost all (100\%) of the studies were employed from 31 December 2019 and 13 April 2020. Among those, 11 (55\%) researches were conducted in China [16,18,20-23,28-30,32,33]. About $3(15 \%)$ researches were studied in the USA [17,26,27]. The remaining studies (30\%) were conducted in Brazil $(5 \%)$, Switzerland (5\%), California (5\%), Korea (5\%), Hong Kong (5\%), and India (5\%) respectively [14,16, 19,24,25,31]. The ocurance of pandemic COVID-19; SARS-CoV-2 outbreak situation starts from Wuhan, Hubei city, China and transmitted to world countries 
PRISMA Flow Diagram

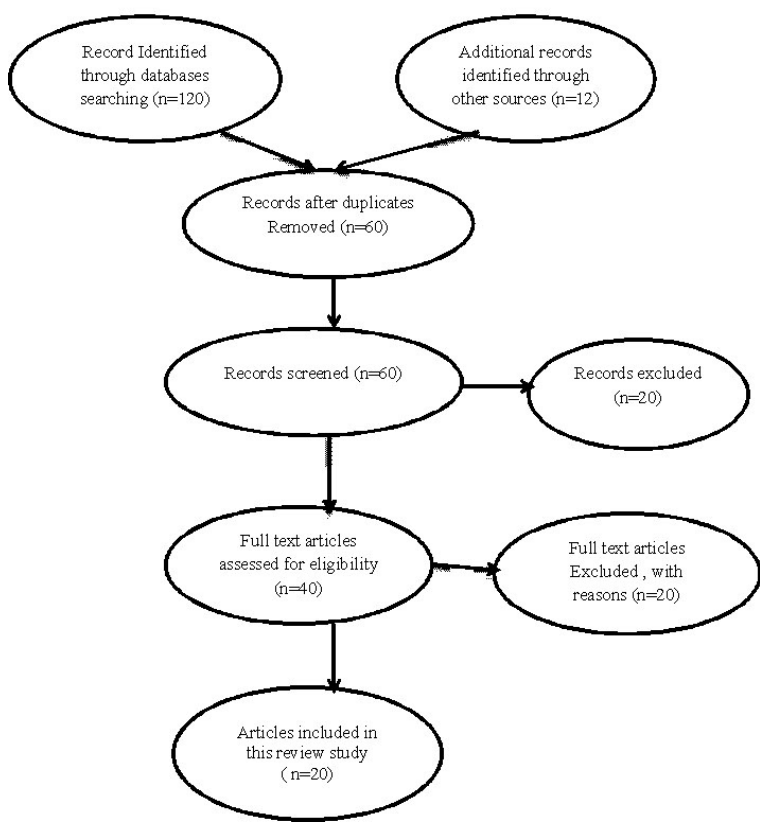

Fig. 1. PRISMA Diagram (Source: Moher, D., Liberati, A., Tetzlaff, J., Altman, DG. The Prisma group (2009). Preferred/Reporting/ Items for systematic Reviews and Meta-analysis: The Prisma Statement.PLOs Med, 6(7): e1000097. dpi: 10.137/journal.pmed10000097).

with diseases manifest itself for all communities without age, gender, ethnicity, religious, position, authority, education, occupation, country, regions, richness, poorness, and color differences among the world population. Eleven of twenty reviewed studies were conducted, suspected cases and deaths reported as well.

Among 20 studies, 6 (30\%) studies analyzed the vulnerability of patients and health professionals with COVID-19 and investigate the clinical outcome of patients with moderate type of COVID-19 after discharged by retesting viral nucleic acid, the epidemiological charactesrtics and dynamics of confirmed COVID-19 cases related with the transmission in Incubation periods of first cases, transmision and its association with population emigration [14,25,28,29,32,33] and, followed by $4(20 \%)$ studies analyzed the development of institutional algorism to protect operating-room team members during the COVID-19 pandemic and rationally conserve personal protective equipment, the incidence of COVID-19 infection among people under home quarantine and its effectiveness and great attention of a preestablished nationally representative Cohort of Weibo user was searched for COVID-19 related key words in their posts $[19,20,23,25]$.
About $3(15 \%)$ studies analyzed the effectiveness of the school closure effects on the COVID-19; SARSCOV-2 outbreak, the public health investigation of a mildly ill, non hospitalized COVID-19 case who traveled to China and how the healthcare provider can support all communities to relieve existing health security capacities against public health risks and events [15,24,26], 2 (10\%) studies analyzed the available evidence about COVID-19 and the International community with a deeper understanding of this new infectious diseases [16,31], 2 two studies (10\%) analyzed the investigating the content of You-tube videos related to COVID-19 gaps in the current knowledge and the incidence of 2019-nCoV infection among people under home quarantine [23,27].

The remaining $3(15 \%)$ studies analyzed the response from various health sectors as such district to generalized hospitals, private and public hospitals, health centers, clinics, and temporary emergency response centers including all other sectors waiting area, the regional blood center, and the hospital-based transfusion services to the events that took place in the community phases of COVID-19 pandemic [17].

The role of the newly established and technological product of internet hospitals during the prevention and control of Novel 2019 infectious pandemic diseases outbreak (COVID-19; SARS-CoV-2) [21], and importance and the main role of community pharmacists' including the content of pharmaceutical care to slow transmission of COVID-19 [22]. Moreover, the review study was focused on the importance of emergency response such as quarantine, isolation, the distance between persons and other prevention and control methods for COVID-19 in various countries as well as key information about the meaning of COVID-19, way of transmission, causes and epidemiologic characteristics, management and ways to prevent and control it.

The majority of the reviewed articles $(65 \%)$ selected a sample size between 1 and 400 [14-16,19,22,25-29, $31,33]$, and followed by $5(25 \%)$ studies were selected a sample size $\geqslant 1200[21,23,25,30,32]$. Meanwhile, $1(5 \%)$ study selected samples between 801 and 1200 peoples [17], and the other $1(5 \%)$ study selected samples between 401 and 800 [18] [Fig. 2].

In this review, $6(30 \%)$ findings utilized a brief history and laboratory examination official cases to identified confirmed diagnosis on COVID-19; SARSCoV-2 outbreaks and to answer the research questions [17,26,29,31-33].

Three $(15 \%)$ of the studies used a situational analysis in order to address the reviewed questions [14,15,25], 


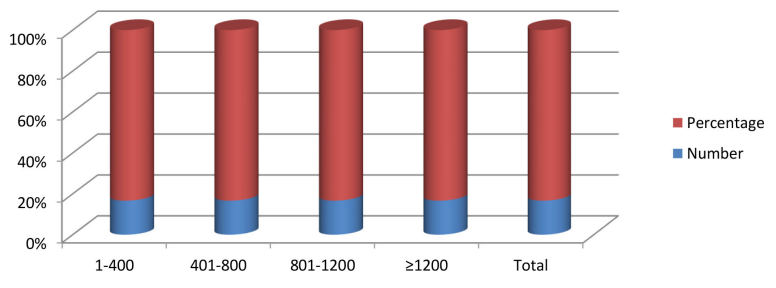

Fig. 2. Total number of sample size of the reviewed articles.

and $3(15 \%)$ studies used an interventional platform PPE taskforce, developed model and simulation study to address review questions [19,20,24]. Only $2(10 \%)$ of the research articles used clinical examination and epidemiological study to answer review questions $[16,28]$ and $2(10 \%)$ studies used descriptive cross-sectional study $[23,27]$. The remaining $4(20 \%)$ studies used an online survey (5\%) [18], a summary of experiences $3(5 \%)$ [22], online epidemic related consultants (5\%) [21] and longitudinal Cohort $3(5 \%)$ [25] to address review questions.

This review had to generalize results from the mentioned articles by identifying a wide variety of the level of risk, effects response to potential health emergencies, prevention, and control methods COVID-19 that might prevent and control the transmission of the infectious pandemic outbreak disease in world nations. These results show the different instruments used to measure the level of risk, effects response, and overall characteristics of COVID-19. Operation room, guideline, well mixed SEIR model, laboratory results, endoscopes, interventional suites and other devices like 'multicenter internet hospitals', which accounted for $55 \%$ of articles on response to potential health emergencies, prevention and control method of COVID-19 was the highly ranked used strategy [19-21,23,24,26-28,30,31,33].

It was followed by $5(25 \%)$ studies list of the hospitalized patient with COVID-19 and the daily number of new confirmed cases [14,16,25,29,32]. The remaining 4 (20\%) studies State Party Annual Reporting (SPAR) tools (5\%) [15], blood supply and transfusion units $(5 \%)$ [17], patient pharmaceutical care and drugs and other supplies (5\%) [22], and the depression, anxiety, and stress scale and the impact of event scale revise (5\%) [18]. About 4 (20\%) of studies were analyzed using situational analysis and response-based analysis to identify the result of the reviewed study [14,17,22,28], and followed by $3(15 \%)$ studies descriptive and logistic regression $[21,23,29]$, and 3 studies $(15 \%)$ follow up and busing channels [25,27,33] whereas $2(10 \%)$ studies were using clinical features and treatment of COVID-19 [16,26], 2 (10\%) studies indicated the epi- demic curve of the period over the period growth rate of the new confirmed cases [30,31]. The remaining 6 $(30 \%)$ studies used various analysis methods to identify the problem and its alternative solution, transmission parameters (5\%) [24], Baidu Qlaux and Correlation ArcGIS and Win Bugs software (5\%) [32], Six Geographic WHO regions (5\%) [15] (Kandel et al., 2020), psychological impact and mental status (5\%) [23], Considering infected individuals as contagious during the latency period (5\%) [20] and develop guideline, health policies and other legislation (5\%) [19].

In this review, $6(30 \%)$ studies used a systematic way of assessing the community and healthcare providers' awareness and beliefs on COVID-19 transmission, prevention, epidemiologic charactesrtics, management and how to implement WHO prevention and control protocol and its purpose to slow COVID-19 transmission [16,17,22,25,27] followed by $4(20 \%)$ studies which assessed and identified the vulnerability of a community contact with suspected and confirmed COVID-19 cases and evaluate its epidemic outbreaks [14,21,26,31] and $4(20 \%)$ studies assessed the main target-related prevention and control, detection, enabling, emergency responses, operational readiness, and public health emergency including efficient and effective hand washing practices [15,24,28,29].

In addition, 3 (15\%) studies detected how we can develop the common algorism for the majority part of COVID-19 transmission methods by using various personal protection equipment and well mixed SEIR Model in order to identify the new case of COVD-19 and how we can control the speed of transmission [19, $20,25]$, and $3(15 \%)$ studies calculated the incidence and basic characteristics of the pandemic COVID-19 outbreak $[23,32,33]$ [Table 1].

In this review, $4(20 \%)$ studies an intervention was focused on older age groups and new migrants and journey-related case groups and/or suspected vulnerable grous $[14,25,31,32]$ followed by $4(20 \%)$ studies suggested that most of the time, infected patients with the COVID-19 infection and having severe symptoms had lower lymphatic counts and higher plasma level of Pt, APTT, D-dimer, LDH, PCT, ALB, CRP, and AST and other laboratory test results [16,26,28,33].

Group transmission has been one possible way to transmit COVID-19 from one area to another since 23 March 2020. The evidence showed that the number of expected cases are lower depending on the time of quarantine and it may change the incidence of COVID-19 in children from 28.4 to 33.6 for 7 and 14 days [24,25], and pharmaceutical effects were one vital management 
Table 1

Level of risk, effects response to potential health emergencies, prevention and control methods of Coronavirus Disease 2019

\begin{tabular}{|c|c|c|c|c|c|c|}
\hline $\begin{array}{l}\text { Author and } \\
\text { year } \\
\text { publication }\end{array}$ & Country & Purpose of the study & Sample size & Methods & Target & $\begin{array}{l}\text { Materials/ } \\
\text { instruments }\end{array}$ \\
\hline $\begin{array}{l}\text { Lima } \\
\text { et al. [14] }\end{array}$ & Brazil & $\begin{array}{l}\text { To assess the susceptibility } \\
\text { of patients and health } \\
\text { professionals with } \\
\text { COVID-19 }\end{array}$ & NA & $\begin{array}{l}\text { Situational } \\
\text { Analysis }\end{array}$ & $\begin{array}{l}\text {-Identify } \\
\text { vulnerable one }\end{array}$ & $\begin{array}{l}\text { Hospitalized } \\
\text { Patient with } \\
\text { COVID-19 }\end{array}$ \\
\hline $\begin{array}{l}\text { Kandel } \\
\text { et al. [15] }\end{array}$ & Switzerland & $\begin{array}{l}\text { To relieve existing health } \\
\text { security capacities against } \\
\text { COVID-19 }\end{array}$ & 182 Countries & $\begin{array}{l}\text { Situational } \\
\text { Analysis }\end{array}$ & $\begin{array}{l}\text {-Prevention } \\
\text {-Detection } \\
\text {-Responding } \\
\text {-Enabling } \\
\text { Operational } \\
\text { readiness }\end{array}$ & $\begin{array}{l}18 \text { indicators } \\
\text { from the IHR } \\
\text { state party } \\
\text { Annual Reporting } \\
\text { (SPAR) Tools }\end{array}$ \\
\hline $\begin{array}{l}\text { Wan } \\
\text { et al. [16] }\end{array}$ & China & $\begin{array}{l}\text { To provide the awareness of } \\
\text { COVID-19 among } \\
\text { International community }\end{array}$ & 135 countries & $\begin{array}{l}\text { Clinical } \\
\text { assessment }\end{array}$ & $\begin{array}{l}\text { Community } \\
\text { awareness }\end{array}$ & $\begin{array}{l}\text { Hospitalized } \\
\text { Patient with } \\
\text { COVID-19 }\end{array}$ \\
\hline $\begin{array}{l}\text { Pagano } \\
\text { et al. [17] }\end{array}$ & $\begin{array}{l}\text { Washington } \\
\text { DC }\end{array}$ & $\begin{array}{l}\text { To describes the response } \\
\text { of public health emergency } \\
\text { like blood transfusion from } \\
\text { the Hospitals and the } \\
\text { regional blood centers }\end{array}$ & $\begin{array}{l}704 \text { confirmed } \\
\text { cases }\end{array}$ & Brief report & $\begin{array}{l}\text { Encouraging } \\
\text { blood donation } \\
\text { and Community } \\
\text { and healthcare } \\
\text { provider } \\
\text { awareness }\end{array}$ & $\begin{array}{l}\text { Blood supply and } \\
\text { transfusion Units }\end{array}$ \\
\hline $\begin{array}{l}\text { Wang } \\
\text { et al. [18] }\end{array}$ & China & $\begin{array}{l}\text { To survey the level of } \\
\text { knowledge on mental } \\
\text { health condition and stress } \\
\text { during the initial of the } \\
\text { COVID-19 outbreak }\end{array}$ & $\begin{array}{l}1210 \\
\text { respondents } \\
\text { from } 194 \text { cities }\end{array}$ & Online survey & $\begin{array}{l}\text {-Precautionary } \\
\text { measures against } \\
\text { COVID-19 }\end{array}$ & $\begin{array}{l}\text {-The impact of } \\
\text { Event Scale } \\
\text { Revise (IES-R) } \\
\text {-Depression, } \\
\text { Anxiety and } \\
\text { Stress Scale } \\
\text { (DASS-21) }\end{array}$ \\
\hline $\begin{array}{l}\text { Forrester } \\
\text { et al. [19] }\end{array}$ & California & $\begin{array}{l}\text { To develop an Institutional } \\
\text { algorism to protect } \\
\text { operating room team } \\
\text { members during the } \\
\text { COVID-19 pandemic }\end{array}$ & NA & $\begin{array}{l}\text { An interventional } \\
\text { platform PPE } \\
\text { taskforce }\end{array}$ & $\begin{array}{l}\text {-Developing } \\
\text { common } \\
\text { algorithm for } \\
\text { PPE user }\end{array}$ & $\begin{array}{l}\text {-Operating room } \\
\text {-Interventional } \\
\text { suites } \\
\text {-Endoscopes } \\
\text {-Guidelines }\end{array}$ \\
\hline $\begin{array}{l}\text { Hou } \\
\text { et al. [20] }\end{array}$ & China & $\begin{array}{l}\text { To explore the effectiveness } \\
\text { of the quarantine }\end{array}$ & NA & $\begin{array}{l}\text { A well mixed } \\
\text { sustainable } \\
\text { exposed } \\
\text { infectious } \\
\text { recovered } \\
\text { compartmental } \\
\text { Model }\end{array}$ & $\begin{array}{l}\text { The dynamic of } \\
\text { the COVID-19 } \\
\text { epidemic } \\
\text {-Epidemiological } \\
\text { charactesrtics of } \\
\text { Individual }\end{array}$ & $\begin{array}{l}\text { Well-Mixed SEIR } \\
\text { Model }\end{array}$ \\
\hline $\begin{array}{l}\text { Gong } \\
\text { et al. [21] }\end{array}$ & China & $\begin{array}{l}\text { To explore the role of } \\
\text { internet hospitals during the } \\
\text { prevention and control of } \\
\text { COVID-19 }\end{array}$ & $\begin{array}{l}4913 \\
\text { consultants }\end{array}$ & $\begin{array}{l}\text { Online epidemic } \\
\text { related } \\
\text { consultants }\end{array}$ & $\begin{array}{l}\text { Compared with } \\
\text { reported } \\
\text { COVID-19 } \\
\text { patients }\end{array}$ & $\begin{array}{l}\text { Multicenter } \\
\text { internet hospitals }\end{array}$ \\
\hline $\begin{array}{l}\text { Zheng } \\
\text { et al. [22] }\end{array}$ & China & $\begin{array}{l}\text { To address community } \\
\text { pharmacists' role and the } \\
\text { content of pharmaceutical } \\
\text { care during the novel } \\
\text { COVID pandemic }\end{array}$ & $\begin{array}{l}\text { Community } \\
\text { Pharmacy } \\
\text { management } \\
\text { team }\end{array}$ & $\begin{array}{l}\text { Summary the } \\
\text { experience }\end{array}$ & $\begin{array}{l}\text { Safe drugs use of } \\
\text { the community, } \\
\text { patient and } \\
\text { population }\end{array}$ & $\begin{array}{l}\text { Patient } \\
\text { pharmaceutical } \\
\text { care }\end{array}$ \\
\hline Wang. [23] & China & $\begin{array}{l}\text { To estimate the incidence of } \\
\text { 2019-nCoV infection } \\
\text { among people under home } \\
\text { quarantine }\end{array}$ & 2004 people & $\begin{array}{l}\text { Descriptive cross } \\
\text { sectional study }\end{array}$ & $\begin{array}{l}\text {-To calculate the } \\
\text { incidence }\end{array}$ & $\begin{array}{l}\text {-laboratory } \\
\text { results }\end{array}$ \\
\hline $\begin{array}{l}\text { Kim } \\
\text { et al. [24] }\end{array}$ & Korea & $\begin{array}{l}\text { To quality the school } \\
\text { closure effects on the } \\
\text { COVID-19 epidemic }\end{array}$ & 60 cases & $\begin{array}{l}\text { Mathematical } \\
\text { Model and } \\
\text { simulation study }\end{array}$ & $\begin{array}{l}\text { Assess the school } \\
\text { closure and its } \\
\text { value }\end{array}$ & $\begin{array}{l}\text { Mathematical } \\
\text { Model }\end{array}$ \\
\hline $\begin{array}{l}\text { Zhu } \\
\text { et al. [25] }\end{array}$ & Hongkong & $\begin{array}{l}\text { To measure the attention of } \\
\text { Chinese netizens to } \\
\text { COVID-19 }\end{array}$ & $\begin{array}{l}1101 \text { Weibo } \\
\text { accounts }\end{array}$ & $\begin{array}{l}\text { Longitudinal } \\
\text { Cohort }\end{array}$ & $\begin{array}{l}\text { Attention quickly } \\
\text { increased }\end{array}$ & Weibo Accounts \\
\hline
\end{tabular}


Table 1, continued

\begin{tabular}{|c|c|c|c|c|c|c|}
\hline $\begin{array}{l}\text { Author and } \\
\text { year of } \\
\text { publication }\end{array}$ & Country & Purpose of the study & Sample size & Methods & Target & $\begin{array}{l}\text { Materials/ } \\
\text { instruments }\end{array}$ \\
\hline $\begin{array}{l}\text { Scott } \\
\text { et al. [26] }\end{array}$ & USA & $\begin{array}{l}\text { To describe the public } \\
\text { health investigation of a } \\
\text { mildly ill, non hospitalized } \\
\text { COVID-19 case who } \\
\text { travelled to China }\end{array}$ & 35 specimens & $\begin{array}{l}\text { Laboratory } \\
\text { diagnostic evalua- } \\
\text { tion/Report }\end{array}$ & $\begin{array}{l}\text { Assess the } \\
\text { investigation } \\
\text { results }\end{array}$ & Specimens \\
\hline $\begin{array}{l}\text { Basch } \\
\text { et al. [27] }\end{array}$ & United State & $\begin{array}{l}\text { To address the investigating } \\
\text { the content of You tube } \\
\text { videos related to } \\
\text { COVID-19 }\end{array}$ & $\begin{array}{l}100 \text { You tube } \\
\text { videos }\end{array}$ & $\begin{array}{l}\text { Cross sectional } \\
\text { study }\end{array}$ & $\begin{array}{l}\text { Assess the gap in } \\
\text { the current } \\
\text { awareness }\end{array}$ & You Tube Videos \\
\hline $\begin{array}{l}\text { Xiao } \\
\text { et al. [28] }\end{array}$ & China & $\begin{array}{l}\text { To analyze the } \\
\text { epidemiological } \\
\text { charactesrtics of a cluster } \\
\text { COVID-19 }\end{array}$ & $\begin{array}{l}5 \text { cases in } \\
\text { January, } 2020\end{array}$ & $\begin{array}{l}\text { The National } \\
\text { health } \\
\text { Commission, a } \\
\text { field } \\
\text { epidemiological } \\
\text { survey }\end{array}$ & $\begin{array}{l}\text {-Find out the } \\
\text { source and } \\
\text { transmission } \\
\text { chain }\end{array}$ & $\begin{array}{l}\text {-Nasopharyngeal } \\
\text { swabs -Sputum } \\
\text { sample }\end{array}$ \\
\hline $\begin{array}{l}\text { Cao } \\
\text { et al. [29] }\end{array}$ & China & $\begin{array}{l}\text { To describe the } \\
\text { epidemiologic } \\
\text { charactesrtics of COVID-19 }\end{array}$ & $\begin{array}{l}135 \text { confirmed } \\
\text { cases, } 3 \text { deaths, } \\
\text { and } 87 \\
\text { recoveries }\end{array}$ & $\begin{array}{l}\text { Daily notification } \\
\text { Report }\end{array}$ & $\begin{array}{l}\text { To provide } \\
\text { scientific of } \\
\text { prevention and } \\
\text { control measures }\end{array}$ & $\begin{array}{l}\text { Data from } \\
\text { COVID-19 cases }\end{array}$ \\
\hline $\begin{array}{l}\text { Zhu } \\
\text { et al. [30] }\end{array}$ & China & $\begin{array}{l}\text { To evaluate the } \\
\text { epidemiologic dynamics of } \\
\text { COVID-19 }\end{array}$ & $\begin{array}{l}50,031 \\
\text { Confirmed } \\
\text { cases } \\
\text { (COVID-19) }\end{array}$ & $\begin{array}{l}\text { Analysis and } \\
\text { reports }\end{array}$ & $\begin{array}{l}\text { To master the } \\
\text { epidemic trend of } \\
\text { COVID-19 }\end{array}$ & $\begin{array}{l}\text { Daily number of } \\
\text { new confirmed } \\
\text { COVID-19 }\end{array}$ \\
\hline $\begin{array}{l}\text { Khot and } \\
\text { Nadkar. [31] }\end{array}$ & India & $\begin{array}{l}\text { To review the available } \\
\text { evidence of Novel } 2019 \\
\text { Corona Virus outbreak }\end{array}$ & NA & $\begin{array}{l}\text { Investigation/ } \\
\text { Diagnostic } \\
\text { confirmation }\end{array}$ & $\begin{array}{l}\text { Evaluate of a new } \\
\text { corona virus } \\
\text { epidemic }\end{array}$ & PCR \\
\hline $\begin{array}{l}\text { Chen } \\
\text { et al. [32] }\end{array}$ & China & $\begin{array}{l}\text { To determine case } \\
\text { distribution and its } \\
\text { correlation with population } \\
\text { emigration }\end{array}$ & 9805 cases & $\begin{array}{l}\text { Official case } \\
\text { report }\end{array}$ & $\begin{array}{l}\text {-Early warning } \\
\text {-Prevention of } \\
\text { future outbreaks }\end{array}$ & $\begin{array}{l}\text { Data on } \\
\text { population } \\
\text { migration }\end{array}$ \\
\hline $\begin{array}{l}\mathrm{Li} \\
\text { et al. [33] }\end{array}$ & China & $\begin{array}{l}\text { To investigate the clinical } \\
\text { outcome of patients with } \\
\text { moderate type of Corona } \\
\text { Virus } 2019 \text { (COVID-19) } \\
\text { after discharged }\end{array}$ & 7 Patients & $\begin{array}{l}\text { Test } \\
\text { SARS-CoV-2 } \\
\text { nuecleic acid by } \\
\text { RT-PCR mtods }\end{array}$ & $\begin{array}{l}\text { Assess the over } \\
\text { all clinical out } \\
\text { comes related } \\
\text { with Death }\end{array}$ & $\begin{array}{l}\text {-Documentation } \\
\text {-Sputum or nasal } \\
\text { swab -Feces }\end{array}$ \\
\hline
\end{tabular}

system for COVID-19 but there is still no effective medicine to manage COVID-19 or vaccine to protect transmissions [22,23].

About $2(10 \%)$ studies identified that the capacity to prevent, investigate, and control COVID-19 varies from country to country, which indicates a wide variety of implementation of control methods to slow COVID transmission $[15,20]$. The finding showed that the world communities are vulnerable to COVID-19 and rated the psychological and mental impact from moderate to severe stages $[23,25]$. The remaining $4(20 \%)$ studies showed that a decision-tree algorism is used to describe the health institution guideline for actioning any precautions for all departments and most of the time, operation-room team members [19], emergency-based treatments like blood transfusions are a significantly observed treatment for COVID-19 in the first week of the disease outbreak occurring in China [17].
Most of the reviewed studies results showed that the case fatality and the incidence of COVID-19 was $22 \%$ and 8-65/1000000, respectively [29] and fewer than one-third of the videos covered any of the seven key prevention behaviors listed on the United States Centers For Diseases Control and Prevention websites [27].

The review showed that COVID-19; SARS-CoV-2 is one of the most killer diseases of global communities and it needs urgent public health emergency to slow transmissions. Therefore, this review was identified as various problems related to COVIOD-19 and its conclusion. Six $(30 \%)$ of studies suggested that there is a shortage of community and healthcare-provider awareness and lack of training for health professionals related to the psychological and environmental impact of COVID-19 [14,20,25-28], and followed by the epidemic prevention and control measures taken by the state and government at all level of health shown very significant effects [29-32]. In another way, 3 (15\%) of 
studies agreed that the implementation of efficient and effective potential health emergency response are critically important to slow COVID-19 transmission from person to person in world nations $[15,18,22]$.

The remaining $7(35 \%)$ studies suggested that the possibility of massive transmission in the children's age group is lower [24], there is a relatively high incidence of positive viral nucleic acid in patients who met the 'discharge from hospital' criteria [33], some of the viral pneumonia cases were treated with scientifically approved traditional Chinese medicine and other drugs like Kaletera as combination form [16].

Moreover, around the globe, most of the district to specialized hospital activities have been switched from day to day activities and operations to COVID19 and overall, people and routine activities are highly disrupted in both developing and developed countries [17,21]. There is also agreement that internet hospitals can serve various kinds of endemic, epidemic, pandemic and sporadic diseases outbreaks, and offer special to the community at the time of the COVID19 outbreak and lower psychological impact of the COVID-19 [18] including ensuring optimal healthcare workers safety are vital to slow COVID-19 transmission [19].

Seven $(35 \%)$ of the studies reviewed recommended that mass quarantine and isolation action must be given great attention by government and communities [14,18,20,27-29,31] because it helps to slow COVID-19 transmission and decrease the morbidity and mortality rate in both low, middle and high-income countries. Five (25\%) studies suggested that currently, COVID-19 is one of the most serious public-emergency and life-threatening problems; therefore facilitating the epidemiology screening and proactive communication of early warning in transparent manners and behaviors [16,21,25,30,32]. Two $(10 \%)$ studies recommended that formulating psychological management and follow-up, including viral testing, should be implemented to identify the severity, magnitude, negative and positive result and/or confirmed cases and total death of the COVID-19 infected persons $[18,33]$. The remaining $6(30 \%)$ studies indicated that capacity building and collaboration between countries is critically important (5\%) [15]. Further studies related to newly proved combined medication like Kaletera and Chinese traditional medicine in the treatment of COVID-19 is advisable [16].

For emergency care, blood transfusion and the utilization of existing supportive managements it healthcare providers are encouraged to take precautions be- fore, during and after operating room activities [19], prepare a community-based pharmacy [22] and the state and government should develop various health and health-related models and simulations are the most commonly advised recommendations to slow COVID19 transmission across the world [24] [Table 2].

\subsection{Confirmed Cases, Recovered and Deaths due to Coronavirus Disease 2019}

The reviews indicated the highest confirmed COVID19 cases, 764,177 patients were registered from the USA starting from the onset of the disease up to 13 April 2020, and followed by Spain accounted 198,674 confirmed cases. However, the lowest COVID-19 confirmed cases, only one case was reported in Yemen, and still, nothing COVID-19 cases and deaths occurred in Bosnia and Herzegovina or Antarctica. Regarding deaths, the most deaths, 40,591 were registered in the United States and followed by 23,660 deaths in Italy, 21,238 in Spain, 19,718 in France, 16,060 in the United Kingdom, 5,683 in Belgium, 5,118 in Iran, 4,632 in China, 4586 in Germany, 3,684 in Netherland, 2,462 in Brazil, 2017 in Turkey, 1,587 in Canada, 1,540 in Sweden, 1,393 in Switzerland and the lowest rate of deaths it means the countries which had registered only one death per their confirmed COVID-19 cases from December 2019 up to 13 April 2020 were reached $15(\mathrm{Bu}-$ rundi, Burundi, Gabon, Liechtenstein, Cape Verde, cayman islands, Libya, Benin, Botswana, Curacao, British version Islands, Suriname, the Gambia, and Mauritania) [34].

However, a total of 39 countries: Rwanda, Gibraltar, Cambodia, Madagascar, Reunion, Vietnam, Faroeisland, FrenchIslands, French Guinea, French Polynesia, Uganda, Maldives, Macao, Eriteria, Mozambique, Sierra Leone, Chad, Mongolia, Nepal, Timer-Leste, Laos, New Caledonia, Fiji, Dominica, Nambia, Saint Lucia, Saint Barthelemy, Falkland Island (Islas Malvinas), Green lands, Monsterrat, Seychelles, Vatican city, Papua New Guinea, Bloutan, South Sudan, Anguilla, and Yemen have had not any death (Zero Death Number) from their registered total number of confirmed cases as active and closed cases of COVID-19. The result also showed that there was no death report within 11 confirmed cases it means that either zero, one, or more deaths registered in the Aland Islands [33,34] [Table 3].

The Coronavirus disease 19 outbreak has affected many countries worldwide. A total of 1,617,191 people were vulnerable with active cases of COVID-19. 
Table 2

The study used to identify the level of risk, effects response to potential health emergencies, prevention and control methods of Coronavirus Disease 2019

\begin{tabular}{|c|c|c|c|c|}
\hline $\begin{array}{l}\text { Author and year } \\
\text { of publication }\end{array}$ & Analysis & Results & Conclusion & Recommendation \\
\hline $\begin{array}{l}\text { Lima } \\
\text { et al. [14] }\end{array}$ & Situational & $\begin{array}{l}\text { The majority of the } \\
\text { interventions were focused on } \\
\text { older people and new migrants }\end{array}$ & $\begin{array}{l}\text { Lack of training for providing } \\
\text { mental health care }\end{array}$ & $\begin{array}{l}\text { Fear seems more certainly a } \\
\text { consequence of mass quarantine }\end{array}$ \\
\hline $\begin{array}{l}\text { Kandel } \\
\text { et al. [15] }\end{array}$ & $\begin{array}{l}\text { Six Geographic } \\
\text { WHO regions }\end{array}$ & $\begin{array}{l}\text { Countries vary widely in terms } \\
\text { of their capacity to prevent, } \\
\text { detect and respond to outbreak }\end{array}$ & $\begin{array}{l}\text { An effective response to potential } \\
\text { health emergencies could be } \\
\text { enabled }\end{array}$ & $\begin{array}{l}\text { Capacity building and } \\
\text { collaboration between countries } \\
\text { are needed to strengthen global } \\
\text { readiness for outbreak control }\end{array}$ \\
\hline $\begin{array}{l}\text { Wan } \\
\text { et al. [16] }\end{array}$ & $\begin{array}{l}\text { Clinical features } \\
\text { and treatment of } \\
\text { COVID-19 }\end{array}$ & $\begin{array}{l}\text { The severe cases had lower } \\
\text { lymphocytes counts and high } \\
\text { plasma level }\end{array}$ & $\begin{array}{l}\text { Kaletra and Traditional Chinese } \\
\text { medicine played an important } \\
\text { role in the treatment of the viral } \\
\text { pneumonia }\end{array}$ & $\begin{array}{l}\text { Further studies are required to } \\
\text { explore the role of Kaletra and } \\
\text { traditional Chinese medicine in } \\
\text { the treatment of COVID-19 }\end{array}$ \\
\hline $\begin{array}{l}\text { Pagano } \\
\text { et al. [17] }\end{array}$ & $\begin{array}{l}\text { Response based } \\
\text { analysis }\end{array}$ & $\begin{array}{l}\text { Blood donations dropped } \\
\text { significantly in the first week of } \\
\text { COVID-19 occurring in the } \\
\text { country }\end{array}$ & $\begin{array}{l}\text { As community activities are } \\
\text { disrupted and hospital activities } \\
\text { switch from routine, operations } \\
\text { to pandemic focus }\end{array}$ & $\begin{array}{l}\text { Urgent care oriented, the blood } \\
\text { supply and utilization requires of } \\
\text { transformations }\end{array}$ \\
\hline $\begin{array}{l}\text { Wang } \\
\text { et al. [18] }\end{array}$ & $\begin{array}{l}\text { Psychological } \\
\text { impact and } \\
\text { mental health } \\
\text { Status assessment } \\
\text {-Descriptive } \\
\text { statistics }\end{array}$ & $\begin{array}{l}\text { Most of respondents rated the } \\
\text { psychological impact of the } \\
\text { outbreak as moderate to severe }\end{array}$ & $\begin{array}{l}\text { Specific up to date and accurate } \\
\text { health infection and particular } \\
\text { precaution measure were } \\
\text { associated with a lower } \\
\text { psychological impact of the put } \\
\text { break }(\mathrm{P}<0.005)\end{array}$ & $\begin{array}{l}\text { Formulate psychological } \\
\text { interventions to improve the } \\
\text { mental health of vulnerable } \\
\text { groups during the COVID-19 } \\
\text { epidemic }\end{array}$ \\
\hline $\begin{array}{l}\text { Forrester } \\
\text { et al. [19] }\end{array}$ & $\begin{array}{l}\text { Developing } \\
\text { Guidelines by } \\
\text { conjunction with } \\
\text { our infectious } \\
\text { diseases experts }\end{array}$ & $\begin{array}{l}\text { A decision tree algorism } \\
\text { describing our Institutional } \\
\text { guideline for precautions for } \\
\text { operating room team members } \\
\text { was created }\end{array}$ & $\begin{array}{l}\text { To ensure optimal healthcare } \\
\text { workers safety }\end{array}$ & $\begin{array}{l}\text { To encourage the healthcare } \\
\text { professional should take } \\
\text { precautions before, during and } \\
\text { after operating room activities }\end{array}$ \\
\hline $\begin{array}{l}\text { Hou } \\
\text { et al. [20] }\end{array}$ & $\begin{array}{l}\text { Considering } \\
\text { infected } \\
\text { individuals as } \\
\text { contagious during } \\
\text { the latency period }\end{array}$ & $\begin{array}{l}\text { The possible impact of } \\
\text { questionnaire and isolation } \\
\text { intervention on diseases } \\
\text { infectious }\end{array}$ & $\begin{array}{l}\text { By reducing the contact rate of } \\
\text { latent individual, quarantine and } \\
\text { isolation could be effectively } \\
\text { reduce the potential peak number } \\
\text { of COVID-19 }\end{array}$ & $\begin{array}{l}\text { To initiate the communities upon } \\
\text { quarantine and isolation action to } \\
\text { minimize the risks. }\end{array}$ \\
\hline $\begin{array}{l}\text { Gong } \\
\text { et al. [21] }\end{array}$ & $\begin{array}{l}\text {-Evaluate the } \\
\text { social panic of the } \\
\text { epidemic -logistic } \\
\text { regression model }\end{array}$ & $\begin{array}{l}\text { Reduce the chance of } \\
\text { nasocommial cross infection }\end{array}$ & $\begin{array}{l}\text { Internet hospitals can serve } \\
\text { different types of Epidemic } \\
\text { counselees, offer especial to the } \\
\text { public during COVID-19 }\end{array}$ & $\begin{array}{l}\text { To facilitate epidemiology } \\
\text { screening }\end{array}$ \\
\hline $\begin{array}{l}\text { Zheng } \\
\text { et al. [22] }\end{array}$ & $\begin{array}{l}\text { Analyze the } \\
\text { methods and } \\
\text { strategies }\end{array}$ & $\begin{array}{l}\text { Pharmaceutical care services in } \\
\text { communities during the } \\
\text { COVID-19 shall posses } \\
\text { different properties due to } \\
\text { diseases charactesrtics and } \\
\text { related change in the patients } \\
\text { need }\end{array}$ & $\begin{array}{l}\text { Community pharmacies shall } \\
\text { work as a strong supporter of } \\
\text { patients medication and } \\
\text { protective equipment supply }\end{array}$ & $\begin{array}{l}\text { Community pharmacy shall be } \\
\text { prepared to provide skill and } \\
\text { effective PC services for } \\
\text { community, patient,population to } \\
\text { ensure medication safety and } \\
\text { promote the overall COVID-19 } \\
\text { pandemic control }\end{array}$ \\
\hline Wang. [23] & $\begin{array}{l}\text { Descriptive } \\
\text { analysis }\end{array}$ & $\begin{array}{l}<1 \% \text { participants reported } \\
\text { contact history with confirmed } \\
\text { or suspected cases during their } \\
\text { trip between January, } \\
24-27,2020\end{array}$ & $\begin{array}{l}\text { The incidence of COVID-19 in } \\
\text { the sample was } 1.5 \%\end{array}$ & $\begin{array}{l}\text { Home quarantine is effective } \\
\text { prevention and control } \\
\text { COVID-19 }\end{array}$ \\
\hline $\begin{array}{l}\text { Kim } \\
\text { et al. [24] }\end{array}$ & $\begin{array}{l}\text { Transmission } \\
\text { parameters }\end{array}$ & $\begin{array}{l}\text {-The number of expected cases } \\
\text { for children is } 28.4 \text { for } 7 \text { days } \\
\text { and } 33.6 \text { for } 14 \text { days }\end{array}$ & $\begin{array}{l}\text { The possibility of massive } \\
\text { transmission in the children's age } \\
\text { group is lower }\end{array}$ & $\begin{array}{l}\text { Any government should try to } \\
\text { use the simulation and } \\
\text { mathematical model to reduce } \\
\text { COVID-19 cases }\end{array}$ \\
\hline $\begin{array}{l}\text { Zhu } \\
\text { et al. [25] }\end{array}$ & Follow up & $\begin{array}{l}\text { Attention to COVID-19 was } \\
\text { limited prior to China openly } \\
\text { knowledging human to human } \\
\text { transmission on January, } 2020\end{array}$ & $\begin{array}{l}\text { Limited early warnings } \\
\text { represents missed opportunities } \\
\text { to engage citizens earlier in the } \\
\text { outbreak }\end{array}$ & $\begin{array}{l}\text { Governments should more } \\
\text { proactively communicate early } \\
\text { warnings in a transparent manner }\end{array}$ \\
\hline
\end{tabular}


Table 2, continued

\begin{tabular}{|c|c|c|c|c|}
\hline $\begin{array}{l}\text { Author and year } \\
\text { of publication }\end{array}$ & Analysis & Results & Conclusion & Recommendation \\
\hline $\begin{array}{l}\text { Scott } \\
\text { et al. [26] }\end{array}$ & $\begin{array}{l}\text { High-risk } \\
\text { contact NP/OP } \\
\text { Speciement for } \\
\text { SARS-CoV-2 } \\
\text { testing and } \\
\text { following } 14 \\
\text { days }\end{array}$ & $\begin{array}{l}\text { All tested ( } 35 \text { Speciemen) result } \\
\text { were negative }\end{array}$ & $\begin{array}{l}\text { SARS-CoV-2 infection can cause } \\
\text { mild illness and result in positive } \\
\text { tests for up to } 18 \text { days after } \\
\text { diagnosis, with out evidence of } \\
\text { transmission to close contacts }\end{array}$ & $\begin{array}{l}\text { Public health strategies to mange } \\
\text { individuals with asymptomatic } \\
\text { infection or mild illness }\end{array}$ \\
\hline $\begin{array}{l}\text { Basch } \\
\text { et al. [27] }\end{array}$ & $\begin{array}{l}\text { The videos } \\
\text { viewed over } \\
125 \text { million } \\
\text { times }\end{array}$ & $\begin{array}{l}\text { Fewer than one third of the } \\
\text { videos covered any of the seven } \\
\text { key prevention behaviors listed } \\
\text { on the US centers for diseases } \\
\text { control and prevention website }\end{array}$ & $\begin{array}{l}\text { The results presents an important } \\
\text { missed opportunity for diseases } \\
\text { prevention }\end{array}$ & $\begin{array}{l}\text { Encourge effective preventive } \\
\text { behaviours }\end{array}$ \\
\hline $\begin{array}{l}\text { Xiao } \\
\text { et al. [28] }\end{array}$ & $\begin{array}{l}\text { Multi } \\
\text { prevention and } \\
\text { control } \\
\text { measures } \\
\text { analyzing } \\
\text { transmission } \\
\text { chain }\end{array}$ & $\begin{array}{l}\text { It is the key point for } \\
\text { epidemiological investigation }\end{array}$ & $\begin{array}{l}\text { The epidemiological } \\
\text { investigation indicates that the } \\
\text { transimission might occur in the } \\
\text { Incubation period of COVID-19 } \\
\text { cases }\end{array}$ & $\begin{array}{l}\text { Close attention should be paid to } \\
\text { it further COVID-19 prevention } \\
\text { and control }\end{array}$ \\
\hline $\begin{array}{l}\text { Cao } \\
\text { et al. [29] }\end{array}$ & $\begin{array}{l}\text { Descriptive } \\
\text { analysis }\end{array}$ & $\begin{array}{l}\text { The incidence of COVID- } 19 \text { was } \\
8.65 / 1,000,000 \text { with a } 2.22 \% \\
\text { case fatality rate }\end{array}$ & $\begin{array}{l}\text { People are generally suspectible } \\
\text { to Coronavirus- } 19 \text { which has } \\
\text { shown a familiar cluster }\end{array}$ & $\begin{array}{l}\text { Using synthefic measure for slow } \\
\text { COVID-19 transmission }\end{array}$ \\
\hline $\begin{array}{l}\text { Zhu } \\
\text { et al. [30] }\end{array}$ & $\begin{array}{l}\text { The epidemic } \\
\text { Curve of the } \\
\text { period over } \\
\text { period growth } \\
\text { rate of the new } \\
\text { confirmed cases }\end{array}$ & $\begin{array}{l}\text { There was declining the peak of } \\
\text { the number of new confirmed } \\
\text { cases in the country }\end{array}$ & $\begin{array}{l}\text { The epidemic prevention and } \\
\text { control measures taken by the } \\
\text { state and government at all levels } \\
\text { have shown very significant } \\
\text { effect }\end{array}$ & $\begin{array}{l}\text { Efficiency curbing the spread of } \\
\text { the COVID- } 19 \text { epidemic in } \\
\text { China }\end{array}$ \\
\hline $\begin{array}{l}\text { Khot and } \\
\text { Nadkar. [31] }\end{array}$ & $\begin{array}{l}\text { Every decades } \\
\text { has witnessed } \\
\text { the evalauation } \\
\text { of a new } \\
\text { Coronavirus } \\
\text { epidemics }\end{array}$ & $\begin{array}{l}\text {-Management is primarly } \\
\text { supportive, with never antivirals } \\
\text { Lopinavir, Ritonavir and } \\
\text { Remedesivi -Vigilant screening } \\
\text { of suspected cases and their } \\
\text { contacts is important }\end{array}$ & $\begin{array}{l}\text { The standard infection control } \\
\text { and prevention techniques should } \\
\text { be followed -Controlling this } \\
\text { highly tranmsmissiable diseases } \\
\text { requires international } \\
\text { co-ordination }\end{array}$ & $\begin{array}{l}\text { Isolation of symptoms cases and } \\
\text { home quaranitine is } \\
\text { asymptomatic contacts is } \\
\text { recommended }\end{array}$ \\
\hline $\begin{array}{l}\text { Chen } \\
\text { et al. [32] }\end{array}$ & $\begin{array}{l}\text { Baidu QIanxi } \\
\text { and Correlation }\end{array}$ & $\begin{array}{l}\text { The number of cases in some } \\
\text { cities in China was relatively low }\end{array}$ & $\begin{array}{l}\text { Some cities with a low number } \\
\text { of cases should be a rapid } \\
\text { increases in case load }\end{array}$ & $\begin{array}{l}\text { Understanding the risk trends in } \\
\text { different region is crucial to } \\
\text { ensure preparedness at birth the } \\
\text { individual }\end{array}$ \\
\hline $\begin{array}{l}\mathrm{Li} \\
\text { et al. [33] }\end{array}$ & $\begin{array}{l}\text { Three weeks } \\
\text { quarantined } \\
\text { period }\end{array}$ & $\begin{array}{l}\text { There had no any sign and } \\
\text { symptoms during the quarantine } \\
\text { period in all } 7 \text { patients. }\end{array}$ & $\begin{array}{l}\text { There is a relatively high } \\
\text { incidence of positive viral } \\
\text { nucleic acid in patients met the } \\
\text { discharge criteria }\end{array}$ & -Follow up viral testing \\
\hline
\end{tabular}

Among those active cases, the majority $1,562,980$ $(97 \%)$ cases were mild and 54,211 (3\%) active cases were in a serious or critical condition [Fig. 3].

A total of 790,276 people were affected with closed cases which had an outcome globally. The majority, $625,202(79 \%)$ had recovered from the temporary waiting areas, public health emergency centers, hospitals, health centers, and isolation areas and 165,074 (21\%) died from a total of closed cases [Fig. 4].

During this systematic review; under management process or active cases 1,617,191 (77\%), deaths 165,074 (7\%), and recovered clients 625,202 (26\%) had accounted from the the total $2,407,467$ confirmed cases of COVID 19. The disease outbreak is serious, showing that there are more than 892 new cases, greater than 43 new deaths, 309 a total cases/ 1 million population, and 21.2 deaths/1million population from December 2019 up to April 202020 [Fig. 5].

\section{Discussions}

This review suggested that the awareness of the community and healthcare providers on COVID-19 prevention and control methods and its implementations is lower than other public health problems. Moreover, lack of public health emergency and access to vaccine and medication for appropriate management of COVID-19 
160 A.A. Gebru et al. / The Level of risk, Effects response to potential health Emergencies, Prevention and control method of COVID-19

Table 3

Total confirmed cases per 1 million people, recovered and deaths due to Coronavirus Disease 2019

\begin{tabular}{|c|c|c|c|c|}
\hline Location & Confirmed & Cases per 1 million people & Recovered & Deaths \\
\hline Worldwide & $2,402,076$ & 308.92 & 623,911 & 165,106 \\
\hline United States & 764,177 & $2,318.81$ & 70,172 & 40,591 \\
\hline Spain & 198,674 & $4,218.1$ & 77,357 & 21,238 \\
\hline Italy & 178,972 & $2,970.81$ & 47,055 & 23,660 \\
\hline Germany & 145,184 & $1,746.06$ & 83,438 & 4,586 \\
\hline United Kingdom & 120,067 & $1,807.27$ & - & 16,060 \\
\hline France & 112,606 & $1,678.78$ & 36,578 & 19,718 \\
\hline Turkey & 86,306 & $1,037.89$ & 11,976 & 2,017 \\
\hline China & 82,747 & 59.02 & 77,084 & 4,632 \\
\hline Iran & 82,211 & 986.56 & 57,023 & 5,118 \\
\hline Russia & 42,853 & 292.02 & 3,291 & 361 \\
\hline Brazil & 38,654 & 182.9 & 14,026 & 2,462 \\
\hline Belgium & 38,496 & $3,340.38$ & 8,757 & 5,683 \\
\hline Canada & 35,056 & 923.03 & 11,843 & 1,587 \\
\hline Netherlands & 32,655 & $1,871.24$ & - & 3,684 \\
\hline Switzerland & 27,469 & $3,199.07$ & 17,800 & 1,393 \\
\hline Portugal & 20,206 & $1,966.21$ & 610 & 714 \\
\hline India & 16,116 & 11.85 & 2,302 & 519 \\
\hline Peru & 15,628 & 486.38 & 6,811 & 400 \\
\hline Ireland & 15,251 & $3,098.85$ & - & 610 \\
\hline Austria & 14,710 & $1,652.33$ & 10,501 & 452 \\
\hline Sweden & 14,385 & $1,392.08$ & 550 & 1,540 \\
\hline Israel & 13,491 & $1,469.61$ & 3,754 & 172 \\
\hline Japan & 10,807 & 85.8 & 1,069 & 238 \\
\hline South Korea & 10,674 & 206.14 & 8,114 & 236 \\
\hline Chile & 10,088 & 527.97 & 4,338 & 133 \\
\hline Ecuador & 9,468 & 542.37 & 1,061 & 474 \\
\hline Saudi Arabia & 9,362 & 273.6 & 1,398 & 97 \\
\hline Poland & 9,287 & 241.98 & 1,040 & 360 \\
\hline Romania & 8,746 & 450.7 & 1,892 & 434 \\
\hline Pakistan & 8,348 & 38.09 & 1,868 & 168 \\
\hline Mexico & 8,261 & 65.26 & 2,627 & 686 \\
\hline Denmark & 7,384 & $1,268.13$ & 4,141 & 355 \\
\hline Norway & 7,078 & $1,318.66$ & - & 165 \\
\hline United Arab Emirates & 6,781 & 685.61 & 1,286 & 41 \\
\hline Czechia & 6,746 & 630.82 & 1,298 & 186 \\
\hline Australia & 6,606 & 257.39 & 4,230 & 70 \\
\hline Singapore & 6,588 & $1,155.06$ & 768 & 11 \\
\hline Indonesia & 6,575 & 24.63 & 686 & 582 \\
\hline Serbia & 6,318 & 907.27 & 753 & 122 \\
\hline Philippines & 6,259 & 57.69 & 572 & 409 \\
\hline Ukraine & 5,449 & 130.11 & 347 & 141 \\
\hline Qatar & 5,448 & $1,983.05$ & 518 & 8 \\
\hline Malaysia & 5,389 & 164.61 & 3,197 & 89 \\
\hline Belarus & 4,779 & 507.68 & 494 & 47 \\
\hline Dominican Republic & 4,680 & 451.81 & 363 & 226 \\
\hline Panama & 4,467 & $1,058.83$ & 165 & 126 \\
\hline Colombia & 3,792 & 76.77 & 711 & 179 \\
\hline Finland & 3,783 & 684.39 & 1,700 & 94 \\
\hline Luxembourg & 3,550 & $5,782.76$ & 627 & 73 \\
\hline South Africa & 3,158 & 53.73 & 903 & 54 \\
\hline Egypt & 3,144 & 31.38 & 732 & 239 \\
\hline Argentina & 2,930 & 65.2 & 708 & 134 \\
\hline Morocco & 2,855 & 79.62 & 327 & 141 \\
\hline Thailand & 2,765 & 41.59 & 1,928 & 47 \\
\hline Algeria & 2,629 & 61.14 & 1,047 & 375 \\
\hline Moldova & 2,472 & 921.79 & 457 & 67 \\
\hline Bangladesh & 2,456 & 14.59 & 75 & 91 \\
\hline Greece & 2,235 & 208.4 & 269 & 113 \\
\hline Hungary & 1,916 & 196.06 & 250 & 172 \\
\hline
\end{tabular}


Table 3, continued

\begin{tabular}{|c|c|c|c|c|}
\hline Location & Confirmed & Cases per 1 million people & Recovered & Deaths \\
\hline Kuwait & 1,915 & 433.25 & 305 & 7 \\
\hline Bahrain & 1,881 & $1,218.82$ & 762 & 7 \\
\hline Croatia & 1,871 & 459 & 709 & 47 \\
\hline Iceland & 1,771 & $4,861.91$ & 1,328 & 9 \\
\hline Kazakhstan & 1,676 & 89.75 & 401 & 17 \\
\hline Uzbekistan & 1,565 & 45.89 & 225 & 5 \\
\hline Iraq & 1,539 & 39.33 & 1,009 & 82 \\
\hline Estonia & 1,528 & $1,150.29$ & 164 & 40 \\
\hline Azerbaijan & 1,398 & 138.87 & 712 & 19 \\
\hline Slovenia & 1,330 & 635.13 & 192 & 74 \\
\hline Lithuania & 1,298 & 464.65 & 242 & 33 \\
\hline Armenia & 1,291 & 436.52 & 545 & 20 \\
\hline Oman & 1,266 & 271.39 & 233 & 6 \\
\hline North Macedonia & 1,207 & 581.09 & 178 & 51 \\
\hline Slovakia & 1,161 & 212.78 & 229 & 12 \\
\hline New Zealand & 1,105 & 222.11 & 974 & 12 \\
\hline Ghana & 1,042 & 34.41 & 99 & 9 \\
\hline Cuba & 1,035 & 92.33 & 255 & 34 \\
\hline Hong Kong & 1,026 & 136.79 & 602 & 4 \\
\hline Cameroon & 1,017 & 38.31 & 305 & 42 \\
\hline Afghanistan & 993 & 30.81 & 131 & 32 \\
\hline Bulgaria & 894 & 127.71 & 161 & 42 \\
\hline Tunisia & 879 & 74.99 & 43 & 38 \\
\hline Côte d'Ivoire & 847 & 32.8 & 260 & 9 \\
\hline Djibouti & 846 & 784.52 & 102 & 2 \\
\hline Cyprus & 767 & 875.67 & 79 & 12 \\
\hline Latvia & 727 & 381.27 & 88 & 5 \\
\hline Andorra & 713 & $9,194.9$ & 235 & 36 \\
\hline Lebanon & 673 & 98.6 & 99 & 21 \\
\hline Costa Rica & 660 & 130.49 & 112 & 5 \\
\hline Niger & 648 & 29.04 & 117 & 20 \\
\hline Nigeria & 627 & 3.04 & 170 & 21 \\
\hline Guinea & 579 & 47.39 & 87 & 5 \\
\hline Burkina Faso & 576 & 27.6 & 338 & 36 \\
\hline Bolivia & 564 & 49.17 & 31 & 33 \\
\hline Albania & 562 & 197.47 & 314 & 26 \\
\hline Kyrgyzstan & 554 & 84.79 & 133 & 5 \\
\hline Uruguay & 528 & 150.06 & 298 & 10 \\
\hline Kosovo & 510 & 284.02 & 93 & 12 \\
\hline Honduras & 472 & 51.54 & 10 & 46 \\
\hline San Marino & 461 & $13,730.86$ & 60 & 39 \\
\hline Palestine & 437 & 87.81 & 72 & 3 \\
\hline Malta & 427 & 865.14 & 118 & 3 \\
\hline Taiwan & 420 & 17.79 & 189 & 6 \\
\hline Jordan & 417 & 39.16 & 276 & 7 \\
\hline Réunion & 408 & 476.18 & 237 & 0 \\
\hline Georgia & 394 & 105.82 & 86 & 4 \\
\hline Senegal & 367 & 22.64 & 220 & 3 \\
\hline Mauritius & 328 & 259.09 & 208 & 9 \\
\hline Democratic Republic of the Congo & 327 & 3.65 & 26 & 25 \\
\hline Montenegro & 308 & 494.89 & 55 & 5 \\
\hline Isle of Man & 298 & $3,576.83$ & 193 & 6 \\
\hline Mayotte & 271 & $1,184.51$ & 117 & 4 \\
\hline Sri Lanka & 271 & 12.43 & 96 & 7 \\
\hline Kenya & 270 & 5.68 & 67 & 14 \\
\hline Vietnam & 268 & 2.79 & 202 & 0 \\
\hline Guatemala & 257 & 15.48 & 21 & 7 \\
\hline Venezuela & 256 & 7.95 & 117 & 9 \\
\hline Jersey & 245 & $2,294.01$ & - & 12 \\
\hline Guernsey & 239 & $3,806.22$ & 87 & 9 \\
\hline
\end{tabular}


162 A.A. Gebru et al. / The Level of risk, Effects response to potential health Emergencies, Prevention and control method of COVID-19

Table 3, continued

\begin{tabular}{|c|c|c|c|c|}
\hline Location & Confirmed & Cases per 1 million people & Recovered & Deaths \\
\hline Mali & 224 & 11.22 & 42 & 14 \\
\hline Paraguay & 206 & 28.8 & 41 & 8 \\
\hline El Salvador & 201 & 30.99 & 44 & 7 \\
\hline Faroe Islands & 185 & $3,549.23$ & 176 & 0 \\
\hline Jamaica & 173 & 63.45 & 27 & 5 \\
\hline Tanzania & 170 & 3.04 & 11 & 7 \\
\hline Martinique & 163 & 419.99 & 73 & 12 \\
\hline Guadeloupe & 148 & 363.85 & 73 & 8 \\
\hline Rwanda & 147 & 11.88 & 76 & 0 \\
\hline Republic of the Congo & 143 & 25.91 & 11 & 6 \\
\hline Brunei & 138 & 311.93 & 115 & 1 \\
\hline Somalia & 135 & 8.49 & 2 & 7 \\
\hline Gibraltar & 132 & $3,916.8$ & 120 & 0 \\
\hline Cambodia & 122 & 7.98 & 105 & 0 \\
\hline Madagascar & 121 & 4.61 & 39 & 0 \\
\hline Myanmar (Burma) & 111 & 2.04 & 7 & 7 \\
\hline Gabon & 109 & 50.17 & 7 & 1 \\
\hline Ethiopia & 108 & 1.09 & 16 & 3 \\
\hline Northern Cyprus & 108 & 331.29 & 52 & 3 \\
\hline French Guiana & 97 & 340.14 & 69 & 0 \\
\hline Aruba & 97 & 863.69 & 49 & 2 \\
\hline Monaco & 94 & $2,454.31$ & 22 & 3 \\
\hline Sudan & 92 & 2.17 & 8 & 12 \\
\hline Liberia & 91 & 20.33 & 7 & 8 \\
\hline Bermuda & 86 & $1,343.18$ & 35 & 5 \\
\hline Togo & 84 & 11.14 & 49 & 5 \\
\hline Liechtenstein & 81 & $2,090.38$ & 55 & 1 \\
\hline Equatorial Guinea & 79 & 58.16 & 4 & 0 \\
\hline Barbados & 75 & 261.3 & 19 & 5 \\
\hline Sint Maarten & 67 & $1,649.68$ & 12 & 9 \\
\hline Guyana & 65 & 83.04 & 9 & 7 \\
\hline Cape Verde & 61 & 110.81 & 1 & 1 \\
\hline Cayman Islands & 61 & 926.87 & 7 & 1 \\
\hline Zambia & 61 & 3.41 & 33 & 3 \\
\hline The Bahamas & 58 & 150.52 & 10 & 9 \\
\hline French Polynesia & 55 & 199.33 & 19 & 0 \\
\hline Uganda & 55 & 1.36 & 20 & 0 \\
\hline Maldives & 52 & 138.75 & 16 & 0 \\
\hline Libya & 51 & 7.42 & 11 & 1 \\
\hline Guinea-Bissau & 50 & 31.16 & 3 & 0 \\
\hline Haiti & 47 & 4.06 & 0 & 3 \\
\hline Macao & 45 & 66.22 & 17 & 0 \\
\hline Eritrea & 39 & 11.15 & 3 & 0 \\
\hline Mozambique & 39 & 1.3 & 4 & 0 \\
\hline Syria & 39 & 2.23 & 5 & 3 \\
\hline Saint Martin & 37 & $1,035.08$ & 19 & 2 \\
\hline Benin & 35 & 2.98 & 18 & 1 \\
\hline Sierra Leone & 35 & 4.43 & 6 & 0 \\
\hline Chad & 33 & 2.03 & 8 & 0 \\
\hline Mongolia & 32 & 9.67 & 7 & 0 \\
\hline Nepal & 31 & 1.03 & 3 & 0 \\
\hline Zimbabwe & 25 & 1.65 & 2 & 3 \\
\hline Angola & 24 & 0.77 & 6 & 2 \\
\hline Eswatini & 22 & 20.12 & 8 & 1 \\
\hline Botswana & 20 & 8.55 & 0 & 1 \\
\hline Timor-Leste & 19 & 13.7 & 1 & 0 \\
\hline Laos & 19 & 2.67 & 2 & 0 \\
\hline Belize & 18 & 44.07 & 0 & 2 \\
\hline New Caledonia & 18 & 63.78 & 14 & 0 \\
\hline Fiji & 17 & 19.21 & 0 & 0 \\
\hline Malawi & 17 & 0.89 & 3 & 2 \\
\hline
\end{tabular}




\begin{tabular}{|c|c|c|c|c|}
\hline Location & Confirmed & Cases per 1 million people & Recovered & Deaths \\
\hline Dominica & 16 & 222.82 & 8 & 0 \\
\hline Namibia & 16 & 6.51 & 6 & 0 \\
\hline Saint Lucia & 15 & 83.94 & 0 & 0 \\
\hline Grenada & 14 & 125 & 0 & 0 \\
\hline Curaçao & 14 & 88.24 & 11 & 1 \\
\hline Central African Republic & 12 & 2.18 & 4 & 0 \\
\hline Åland Islands & 11 & 368.08 & - & - \\
\hline Falkland Islands (Islas Malvinas) & 11 & - & 2 & 0 \\
\hline Greenland & 11 & 196.14 & 11 & 0 \\
\hline Montserrat & 11 & - & 2 & 0 \\
\hline Seychelles & 11 & 112.68 & 5 & 0 \\
\hline Nicaragua & 10 & 1.55 & 6 & 2 \\
\hline Suriname & 10 & 17.2 & 6 & 1 \\
\hline The Gambia & 10 & 4.26 & 2 & 1 \\
\hline Vatican City & 8 & - & 2 & 0 \\
\hline Mauritania & 7 & 1.72 & 2 & 1 \\
\hline Papua New Guinea & 7 & 0.78 & 0 & 0 \\
\hline Saint Barthélemy & 6 & - & 1 & 0 \\
\hline Burundi & 5 & 0.46 & 0 & 1 \\
\hline Bhutan & 5 & 6.74 & 2 & 0 \\
\hline British Virgin Islands & 4 & 133.2 & 2 & 1 \\
\hline South Sudan & 4 & 0.31 & 0 & 0 \\
\hline Anguilla & 3 & 201.76 & 1 & 0 \\
\hline Yemen & 1 & 0.03 & 0 & 0 \\
\hline Bosnia and Herzegovina & - & - & - & - \\
\hline
\end{tabular}

Source: Data December, 2019-April, 20, 2020; Corona virus (COVID-19) Map google.com [COVID-19$\mathrm{map} / \mathrm{hl}=\mathrm{en}$ [Accessed April, 20, 2020] and Wikipedia]

Active COVID-19 Cases

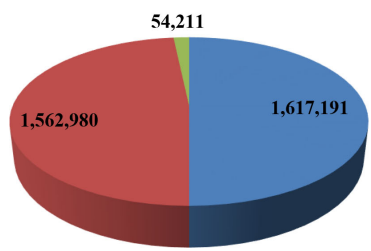

$\varpi$ Currently infected patients

- Mild Condition of COVID-19

- Serious or Critical Condition of COVID-19

Fig. 3. Total number of active cases of COVID-19 outbreak from 31 December 2019 up to 20 April 2020.

\section{Closed COVID-19 Cases}
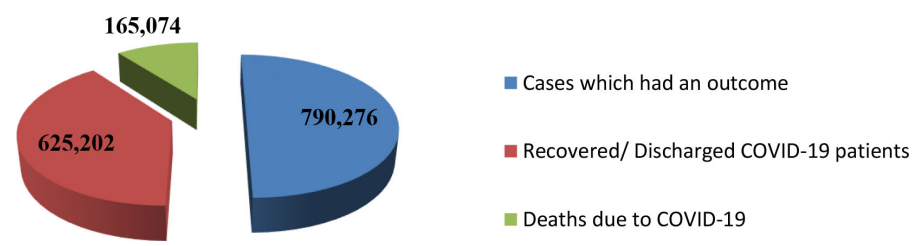

Cases which had an outcome

- Recovered/ Discharged COVID-19 patients

Deaths due to COVID-19

Fig. 4. Total number of closed cases of COVID-19 from December, 2019 up to 20 April, 2020.

outbreak in the world is a serious and growing emergency problem for the community equivalent for the growing more than millions of developing and developed in the world.

This study review, the research team members concluded the results clearly and briefly related to the key relevant literature to the findings of the 20 selected rel- evant articles based on selection criteria. Almost all reviewed studies were reported from December 312020 to 19 April 2020. Most (55\%) of the analysed research articles were from China. This indicated that there were about 44 pneumonia cases with unknown etiology in Wuhan City, Hubei Province of China between 31 December 2019 and 03 January 2020. Meanwhile, after 


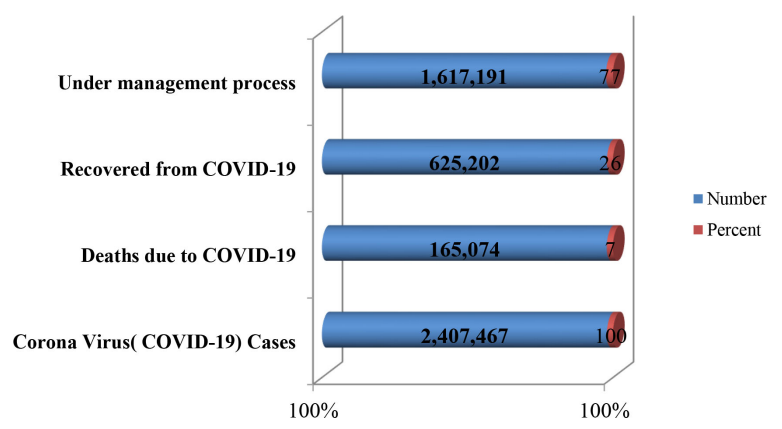

Fig. 5. The total COVID-19 confirmed cases, deaths, recovered and under management process at isolated area,and rehabilitation area from December 2019 to 20 April 2020.

one week of duration, the National Health Commission China reported to the WHO that the epidemic disease outbreak had arisen from contacts in a single seafood market in Wuhan City. However, the Chinese government also confirmed a new COVID-19 epidemic from the infected individual since 07 January 2020 [38].

This section (1) discusses the features of COVID-19; SARS-CoV-2; (2) describes magnitude of public health importance and controlling mechanisms of this disease; (3) rising potential effects of a response to health emergencies, prevention and control methods of COVID-19; (4) describes instruments used to measure causes of COVID-19; (5) identify the level of risk prevention and control methods of COVID-19; furthermore, (6) the result of prevention and control mechanisms of COVID19.

The scholars identified 20 studies, the majority of 6 $(30 \%)$ indicated the vulnerability of patients and health professionals with COVID-19 and investigated the clinical outcome for patients. Similarly, a study conducted in Italy [34] suggested that the newly pandemic diseases outbreak, COVID-19 has threatened the health status of the communities, transportation systems, and trading and business activities including overall commerce in world countries including Italy. Moreover, the epidemiologic and demographic characteristics of previous SARS-CoV-01, MERS-CoV viruses, and experience of an emergency physician in the country's were supported to identify the causes and complications of COVID19 in order to address the issues of COVID-19 [34]. Nonetheless, the reviewed studies showed that most of the world countries have a lack of testing kits for the diagnostic evaluation of COVID-19 and skilled professionals related to new cases of COVID-19. As a result, most of those who died in the community died due to a lack of early diagnosis of their cases and due to the difficulty of differentiating the pathological characteristics of the virus and possibly increased the mortality rate of the population in world nations. Similarly, a study conducted in Fujian, China [35] found that the pathological features of COVID-19 have a great similarity with SARS due to observing symptoms of acute respiratory diseases syndromes; but the latest pathological examination of COVID-19 exposed the clear mucinous secretions in the lungs. Therefore, early recognition of COVID-19 by health professionals and all expertise is still required.

This research showed that the majority of reviewed studies were focused on the importance of emergency response such as quarantine, isolation, the distance between persons and other prevention and control methods for COVID-19 in various countries as well as key information about the meaning of COVID-19, method of transmission, causes and epidemiologic characteristics, management and ways to prevent and control it. However, there is an increasing number of confirmed cases and deaths in both developing and developed countries. In particular, there is increasing socioeconomic crisis and social interaction. This is supported by a recent WHO report of 29 February 2020, which found that the application of travel, and import and export system such as trade restrictions to countries experiencing a COVID-19 outbreak has begun to be implemented. However, it has had significant social and economic effects, and has affected productivity, the resource used for intervention, and all other growth and development stages of every country in the world $[37,38]$.

Similarly, the study conducted in China by [37] agreed that the implementation of a Public Health Emergency of International Concern which was declared by the World Health Organization since the first cases of COVID-19 outbreak happened in China. The implementation of prevention and control strategies like wearing masks, washing hands using soap or sanitizers for effective hand hygiene care practices, spacing the contact between individuals in order to avoid public contact, early diagnosis and overall case detection, contact tracing, and quarantines were the most effective way to reduce COVID-19 transmission [37]. This review indicated that the implications for the importance of improving the work environment to increase awareness of healthcare providers and all communities on the way how to slow COVID-19.

The review revealed several carefully developed instruments and analytic approaches for measuring the level of risk, effects response to potential health emergencies, prevention, and control methods COVID-19. While these measures were developed for a specific 
study, a brief report and laboratory investigation official cases to identified confirmed diagnosis of COVID19; SARS-CoV-2 outbreak and to address the research questions, which accounted for $6(30 \%)$ of the level of risk, the effects a response to potential health emergencies, prevention, and control method of COVID-19 outbreak measurements, was the most used strategy.

The reviewed study also showed that there was a lack of attention to COVID-19 and it was very limited in some of the vulnerable countries and other territories. Therefore, 6 studies identified confirmed diagnosis of COVID-19; the SARS-CoV-2 outbreak. In this regard, there was a decline in the maximum number of new cases confirmed in China and it is relatively low in some cities in the country. It indicated that the lesson learned could help to control the outbreak of diseases in other countries. Moreover, all tested results from 35 specimens were negative. This instrument can provide a useful stepping stone for the further study of slow COVID-19 [39].

In some studies, measures were taken as part of an instrument; however, it is important to use them as measures to identify the level and risk response to emergency public health and prevention and control method of COVID-19 outbreak and to better understanding in health professionals and communities as to how to prevent and control COVID-19 transmission. Furthermore, it is also helpful to investigate the method of response to emerging public health for COVID-19. In the same way as this review, a WHO draft report (3 February 2020) suggested that an instrument such as strategic preparedness and response plan was used to stop further transmission of COVID-19 within China and that this was a critical and important instrument for other countries to mitigate the common impact of COVID-19 outbreak in all countries $[38,39]$.

The majority of these reviewed studies utilized brief reports and laboratory investigations with including official confirmed COVID-19 case approaches to answer the research questions. Meanwhile, a few studies used an online survey, a summary of experience, and longitudinal cohort method which helps to collect, analyze and interpret data. They used this method to assess the phenomenon, process, perspective, and views of healthcare providers and communities as well as governments, policymakers, and other stakeholders. Half of the reviewed studies, however, used various methods to address the research question as such situational analysis, clinical assessment and epidemiological survey, descriptive cross-sectional study, and an interventional plat for PPE task forces, simulation, and model ap- proaches. A quality score based on respondents' opinions within the reviewed studies using a standard form was used to obtain information according to the study design. The majority of reviewed studies frequently used situational and response-based analysis, descriptive and logistic regression, and follow up accompanied by use channels to compute study variables and socioeconomic characteristics including the final result of their studies $[38,39]$.

The findings of this review showed that older age groups and most of the vulnerable groups were the new migrants and journey-related case groups as well as people who are suspected and prone with COVID-19 and related to pandemic disease outbreaks. Similarly, the study was conducted in European countries, the COVID-19 related risk infection for people is higher in older adults in the EU/EEA and UK [40].

The results of this review study showed that the capacity to prevent, investigate, and control the COVID19 outbreak is different from country to country. This indicated that there are a wide variety of methods to slow COVID transmission. Similarly, a study conducted in the UK [41] found that traditional public health prevention and control methods are effective to reduce the maximum number of disease outbreaks, morbidity and mortality rate globally if the countries have an opportunity to implement appropriately but not fully contain the outbreak of COVID-19. It is supported by [42] quarantine, especially complete social distancing has been implemented to slow down the spread of the Coronavirus outbreak (COVID-19) in the USA and many other European countries including Italy [41,42].

The finding also revealed that most of the confirmed cases and patients infected with COVID-19 infection pandemic diseases outbreak and having severe symptoms had lower lymphocyte counts and higher plasma levels and other laboratory test results. Similarly, a study conducted in the USA [43] suggested that the impact of the pandemic COVID-19 outbreak on clinical microbiology laboratories was very high. Therefore, the rapid and accurate diagnosis and monitoring of SARS-CoV-2 infections and greatly assist in the control of this disease outbreak has been implemented using a combined device existing at the point of care with accessible measurements [43].

The review study suggested that in the first week of the COVID-19 outbreak occurred in China, the majority of the healthcare providers were administered blood transfusion as emergency care and there was a significant changed via the result of a safe life. Similarly, the WHO has adopted the Guidance for National Blood 
Services on Protecting the Blood Supply During Infectious Disease Outbreaks $[44,45]$ and risk assessment publications on pandemic COVID-19 outbreak from continental, regional networks and any higher institutions and health sectors [46-48].

\section{Conclusion}

Even though the novel COVID-19 outbreak on 31 December 2019 in Wuhan, Hubei city, China, and countries worldwide, there are normally relevant studies to determine the risk and impact of response to a public health emergency, prevention, and control methods of COVID-19 to slow transmission in countries. The finding showed that there has been an unprecedentedly rapid spread of pandemic COVID-19 outbreak across 212 countries with more than 1.1. million confirmed cases and more than 100,000 deaths worldwide as of 20 April 2020. Therefore, each country's government should be drawn alongside to prevent and control of pandemic COVID-19 outbreak. Moreover, worldwide public health emergency responses with valuable support from the community, health professionals and governments will need to be discussed to find the way to slow COVID-19 transmission and other related action to pandemic diseases.

The WHO declared the COVID-19 outbreak to constitute a public health emergency of international concern since 30 January 2020. The nature of the COVID19 outbreak was changed to pandemic level due to increased transmission, magnitude, severity, morbidity, and mortality rate across the world. Therefore, all governments should create strong partners and collaborate with joint activities using global outbreak prevention and control policy to respond to the COVID-19 emergency and decrease numbers of cases and deaths around the world.

As of today, there are still no any existing and available medicine for the treatment of the COVID-19; SARS-CoV-2 outbreak and still a lack of the effective potential therapeutic agents for other disease outbreaks as such Ebola, SARS-01 and MERS Coronaviruscaused respiratory problems, however, they have a little evidence to manage the symptoms related to previous viral endemic and pandemic disease outbreaks. Hence, there is increasing a probability of COVID-19 transmission among the world communities and the impact of the diseases in world nations.

The reviewed study finding revealed that almost all continents have no pre-existing immunity in the popu- lation against the new COVID-19 and anybody in the communities may be vulnerable to this disease outbreak. This is an issue for world communities and has the potential to kill all populations; therefore, international, national, regional, and local donors should have an important role to play in mitigating the economic impacts of the COVID-19 outbreak. Moreover, a combination of strong national governance, strict rules and regulations, strong healthcare providers and community awareness and citizen involvement, and wise use of big COVID-19 row data and digital technologies are very important to form the basic foundation of mitigation and curative measures of a disease outbreak. The implications of this review study are significant in certain areas of the COVID-19 outbreak which are worthy of further research.

The research team concluded that future research must look at the risk and impacts of a various public health emergency, prevention, and control methods of COVID-19 outbreak and other epidemic and pandemic diseases around the world. Moreover, these must be with respect to incubation periods, how drugs are synthesized, vaccine sources and effectiveness and frequency, the effect of a public health emergency, the impact of COVID-19 on each country's economic, social and environmental growth and development including overall crisis, community health status, and personal and professional skill development to slow COVID-19 transmissions.

Therefore, the optimal duration and frequency of this response to a public health emergency to prevent and control of COVID-19 and to create positive impacts can be verified. In addition, it is valuable to investigate which types of responses to public health emergencies will prevent and control the COVID-19 outbreak effects and which are more targeted. As a result, hand washing with sanitizers, the distance between individuals, call for health professionals, quarantine, isolation, and overall precautionary measures and critical awareness of healthcare providers and communities to slow COVID-19 transmission can be designed accurately and effectively.

The effect of quarantine, especially home quarantine, school closure, and another early warnings as a public health emergency to prevent and control of COVID19 pandemic outbreak transmission was regarded as a positive outcome, but it needs to be implemented with precaution. Therefore, we recommended that the use of various measurements of slow COVID-19 pandemic disease outbreak for comparison of outcomes in future researches. 
Abbreviations

$\begin{array}{ll}\text { ARDS } & \text { Acute Respiratory Distress Syndrome } \\ \text { COVID-19 } & \text { Coronavirus Disease 2019 } \\ \text { HRQoL } & \text { Health-Related Quality of Life } \\ \text { MERS } & \text { Middle East Respiratory Syndrome } \\ \text { SARS } & \text { Severe Acute Respiratory Syndrome } \\ \text { SMSI } & \text { Social Media Search Indexes } \\ \text { SPAR } & \text { State Party Annual Reporting } \\ \text { WHO } & \text { World Health Organization }\end{array}$

\section{Authors' contributions}

AAG designed the review protocol. Both AAG and TB designed the search strategy for this systematic review protocol and performed the search in collaboration with online healthcare librarians. AAG, TB, EW, AFA,SM, HZA, AK, BAT, BAA, BSD, NSZ,AGG, BM, and QKY have participated in data selection, data extraction, data analysis, and interpretation of the results. All authors critically revised, read, and approved the final manuscript.

\section{Acknowledgments}

The authors are grateful to Salale University, Fitche, Ethiopia for the material support. The authors would also like to acknowledge all scientific researchers and scientists, the World Health Organization, the Centre for Disease Prevention and Control; the Ministry of Health, and all those individuals who rendered valuable technical support during the study period.

\section{References}

[1] H.J. Wang, S.H. Du, X. Yue and C.X. Chen, Review and perspect of pathological features of coronavirus diseases, Fayi Xue Zahi 26(1) (2020), 16-20.

[2] T. Singhal, A Review of Coronavirus Disease-2019 (COVID19), Indian J Pediatr 87(4) (2020), 281-286. doi: 10.1007/ s12098-020-03263-6.

[3] Task Force of Pulmonary Function Testing and Clinical Respiratory Physiology, Chinese association of chest physicians; Pulmonary function testing group, respiratory therapeutics group, Chinese thoracic society., expert consensus on pulmonary function testing during the epidemic of corona virus disease 2019. Zhonghua Jie He He Hu Xi Za Zhi 43 (2020). E032. doi: 10.3760/cma.j.cn112147-20200225-00175.

[4] W.Y. Khot and M.Y. Nadkar, The 2019 novel coronavirus outbreak-a global threat, $J$ Assoc Physicians India 68(3) (2020), 67-71.
[5] K.J. Goh, M.C. Choong, E.H. Cheong, S. Kalimuddin, DUUS. Wens, K. PhuaS and S. Hala Mihideen, Rapid progression to acute respiratory distress syndrome: Review to current understanding of critical illness-from COVID-19 Infection. Ann Acad Med Singapore 49(1) (2020), 1-9.

[6] N. Zhu, D. Zhang, W. Wang, X. Li, B. Yang, J. Song, X. Zhao, B. Huang, W. Shi, R. Lu, P. Niu, F. Zhan, X. Ma, D. Wang, W. $\mathrm{Xu}, \mathrm{G}$. Wu, G.F. Gao and W. Tan, The china novel coronavirus investigating and research team., 2020. A novel coronavirus from patients with pneumonia in China, 2019. N Engl J Med 382(8) (2020), 727-733. doi: 10.1056/NEJMoa200101.

[7] S. Batawi, N. Tarazan, R. Al-Raddadi, E. Al Qasim, A. Sindi, S. Al Johni, F.M. Al-Hameed, Y.M. Arabi, T.M. Uyeki and B.M. Alraddadi, Quality of life reported by survivors after hospitalization for Middle East respiratory syndrome (MERS). Health Qual Life Outcomes 17(1) (2019), 101. doi: 10.1186/s12955-019-1165-2.

[8] V. Peyronnet, J. Sibiude, P. Deruelle, C. Huissoud, X5. Lescure, J.C. Lucet, L. Mandelbrot, I. Nisand, C. Vayssière, Y. Yazpandanah, D. Luton and O. Picone, Infection with SARSCoV-2 in pregnancy. Information and Proposed Care. CNGOF. Gynecol Obstet Fertil Senol. (2020), pii: S2468-7189 (20)30110-0. doi: 10.1016/j.gofs.2020.03.014.

[9] L. Quin, Q. Sun, Y. Wang, K.F. Wu, M. Chen, B.C. Shia and S.Y. Wu, Prediction of number of cases of 2019 novel corona virus (COVID-19) Using social media search index. Int J Environ Res Public Health 17(7) (2020). pii: E2365.doi: 10.3390/ijerph17072365.

[10] International Institute for sustainable development, Three ways the corona virus is shaping sustainable development inequality is magnified. (2020). http://www.iisd.org/library/Corona virus shaping sustainable development [Accessed on April, 8, 2020].

[11] Z.B. Zhu, C.K. Zhong, K.X. Zhang, C. Dong, H. Penz, T. $\mathrm{Xu}$, A.L. Wang, Z.R. Guo and Y.H. Zhang, Epidemic trend of corona virus diseases (COVID-19) in mainland China. Zhonghua Yu Fang Yi Xue Za Zhi 54(0) (2020), E022.doi: 10.3760/cma.j.cn 1121-.2020222-00163.

[12] J. Hyun, S.G. Lee and J. Hwang, Application of corona discharge-generated air ions for filtration of aerosolized virus and inactivation of filtered virus, J Aerosol Sci 107 (2017), 31-40. doi: 10.1016/j.jaerosci.2017.02.004. Epub 2017 Feb 11.

[13] S. Agrawal, A.D. Goel and N. Gupta, Emerging prophylaxis strategies against COVID-19, Monaldi Arch Chest Dis 90(1) (2020), doi: 10.4081/monaldi.2020.1289.

[14] C.K.T. Lima, F.M.M. Carvalho, I.A.A.S. Lima, J.V.A.O. Nunes, J.S. Saraiva and R.I. Deseuzu, C.G. de SilvaL and M.R. Neto, The emotional impact of coronavirus 2019-nCoV (new coronavirus diseases), Psychatric Res 12(287) (2020), 112915.

[15] N. Kandel, S. Chungoing, A. Omaar and J. Xing, Health security capacities in the context of COVID-19 out break: An analaysis of international regulations annual report data from 182 countries, Lancet, (2020), S0140-6736:30553-5.

[16] S. Wan, Y. Xiang, W. Fang, Y. Zheng, B. Li, C. Lang, D. Huang, X. Sug, J. Lv, L. Shen, H. Yang, G. Huang and R. Yang, Clinical feature and tratement of COVID-19 patients in Northeacst Chingqing J Med Viro, (2020). doi: 10.1002/ jmv.2583.

[17] M.B. Pagano, J.R. Hess, H.C. Tsango, E. Staley, T. Gernsheimer, N. Ser, C. Clark, J. Nester, C. Bailey and K. Alcon, Prepare to adapt: Blood supply and transfusion support during the first 2 weeks of the 2019 Novel Coronacirus (COVID-19) pandemic affecting Washington state, Transfusion, (2020). doi: 10.1111/trf.15789. 
[18] O. Wang, Y.E. Qiu, J.Y. Li, Z.J. Zhou, C.H. Liao and X.Y. Ge, A unique protease cleavage site predicted ij the sprike protein of the Novel pneumonia Coronavirus (2019-nCoV) potentially related to viral tramnsmissibly, Virologica Sinica, (2020). doi: 10.1007/S12250-020-00212-7.

[19] J.D. Forrester, A.K. Nassar, P.M. Manggio and M.T. Hown, Precautions for operating room team members during the COVID-19 pandemic, JAM Coll Surg, (2020). Pii.S10727515(20)30303-3. doi: 10.1016/J.Jamcollsing.2020.03.030.

[20] C. Hou, J. Chen, Y. Zohou, L. Hua, J. Yuan, S. He, Y. Guo, S Zhang, Q. Ji, C. Zhao, J. Zhang, G. Xu and E. Jiq, The effectiveness of the quarantine of Wuhan Xity against the corona virus diseases 2019 (COVID-19): well-mixed SEIR model analaysis, J Med Viroal, (2020). doi: 10.1002/JMV.25827.

[21] K. Gong, Z. Xu, Z. Cai, Y. Chen and Z. Wang, Internet hospitals help prevent and control the epidemic of COVID-19 in China: A multicenter user profiling study, J Med Internet Res, (2020). doi: 10.2196/18908.

[22] S.Q. Zheng, P.X. Zhou, H.B. Li, F. Livu and R.S. Zhao, Recommendations and gudance for providing pharmaceutical care services during COVID-19 pandemic: A China perspective rews social, Adm Pharm (2020). Pii:51551-7411920: 3028430289. doi: 10.1016/j.scapharm 2020(03).

[23] J. Wang, Y. Liao, Y. Li, D. Jiang, J. He, S. Zhang and J. Xia, Incidnece of novel communities (2019-nCoV-2) infection among people under home quarantine in Shenzhen, China, Travle Med Infction Diseases, (2020). doi: 10.1016/J.Trmaid.2020.101660.

[24] K.R. Kims and E. Jung, School opening delay effect on transmissikons mission dynamics of CORONA VIRUS diseases 2019 in Korea: Based on mathematical modeling and simulation study, J Korea Med Sciences 35913 (2020), e143. doi: 10.3346/jkma.2020.35:e1413.

[25] Y. Zhu, K.W. Fu, K.A. Grepin, H. Liang and I.C. Fung, Limited early warnings and public attention to COVID-19 in China, January-Feburary, 2020: A longitudinal Cohort of randomly sampled weibo users: Diasster med public health prep 3 (2020), 1-9, doi: 10.1017/dmp.2020.68.

[26] S.E. Scott, K. Zabel, J. Collins, J. Hobbs, M.J. Kretschmer, M. Lach, K. Turnbow, L. Speck, J.R. White, K. Maldonando, B. Howard, J. Fower, S. Singh, S. Robinson, A.P. Pampa, K. Chatham-Stephens, A. Xie, J. Cates and R. Suynrnshine, Maricopa country COVID-19 case investigation team, first mildly III, Non-Hospitalized case of Coronavirus Diseases 2019 COVID-190 with out viral transmission in the United States-maricopa Country, Arizona, 2020, Clinic Infec Dis 2020, Apriol 2 pii.ciaa374. (2020), doi: 10.1093/cid/ciaa374.

[27] C.H. Basch, G.C. Hilyer, Z.C. Meleo-Erwin, C. Jaime, J. Mohlman and C.E. Basch, Preventive behaviours conveyed on Youtube to Migrate transmission of COVID-19: Cross sectional Study, JMIR Public Health Serve Ill, 2020, April 2 6(2) (2020), e18807.doi: 10.102196/18807.

[28] W.J. Xiao, Q. Gao, K. Jin, X.H. Gong, R.B. Han, C.Y. Jiangcy, X.J. Jiang, B.H. Jin, Q.W. Fang, H. Pan, N.Y. Wu, and X.D.M. Sun, Investigation of an epidemic cluster caused by COVID19 cases incubation period in Shangi, Zhonghua Liu Xing Xue Za Zhi 41(0) (2020), E033.doi: 10.3760/cma.J.cn11238820200302-00236.

[29] Y.C. Cao, Q.X. Deng and S.X. Dai, Remdesivir for severe acute respiratory syundrome coronavirus 2 causing COVID-19 An evaluation of the evidence, Travel Med Infec Dis (2020), doi: 10.1016/j.trmaid.2020.101647.

[30] Z.B. Zhu, C.K. Zhong, K.X. Zhang, C. Dong, H. Peng, T. Xu, A.L. Wang, Z.R. Guo and ZY.H. Xhang, Epidemic tremnd of coronavirus diseases 2019 (COVID-19) in mainland
China, Zhanghua Yu Fang Yi Xue Za Zhi 54 (2020), E022.doi: 10.3760/cma.j.cn112150-2020222-0016.

[31] W.Y. Khot and M.Y. Nadkar, The 2019 novel coronavirus outbreak-A global threat, $J$ Assoc Physicians India 68(3) (2020), 67-71.

[32] Z.L. Chen, Q. Zhang, Y. Lu, Z.M. Guo, X. Zhang, W.J. Zhang, C. Guo, C.H.J. Liao and Q.L. Li, X. HanH and J.H. Lu, Distribution of the COVID-19 epidemic and correlation withpopulation emigration from Wuhan, China, Chin Med J (Engl), (2020), Pii: 10.1097/CM9(0000000000000782).

[33] Y. Li, Y. Hu, X. Zhang, Y. Yu, B. Li, J. Wu, Y. Wv, X. Xia and J. Xu, Follow-up testing of viral nucleic acid in discharged patient with moderate types of 2019 coronavirus diseases (COVID-19), Zhejiang Dn Xue Xue Bao Yi Xue Ban 49(1) (2020).

[34] A.L. Giwa, A. Desai and A. Duca, Novel 2019 coronavirus SARS-CoV-2 (COVID-19): An updated overview for emergency clinicians, Emerg Med Pract 22(5) (2020), 1-28.

[35] M. Yaquin, W. Lin, J. Wen and Y. Chen, Clinical and pathological charcseterstics of 2019 novel coronaviruses (COVID-19): A systematic review, (2020). doi: 10./10/2020.02-20.20025601.

[36] World Health Organization, Update dWHO recommendation for international traffic in related to COVID-19 outbreak; covid-19 travel Advice, Geneva, Switzerland, WHO. (2020).

[37] S.P. Adhikari, S. Meng, Y.J. Wu, Y.P. Mao, R.X. Ye, Q.Z. Wang, C. Sun, S. Sylvia, S. Rozelle, H. Roat and H. Zhou, Epidemiology, causes, clinical manifestation and diagnosis, prevention and control of Coronavirus disease4s (COVID-19) during the early outbreak period: a scoping review.Infectious Diseases of Poverty 9(29) (2020). 1-10.

[38] World Health Organization, Strategic preparedness and response plan: 2019 novel coronavirus (2019-nCoV). Draft as of 3 Feburary, 2020. WHO, Geneva, Switzerland. (2020).

[39] World Health Organization, Novel coronavirus (2019-nCoV): Situation report-1: Data as reported by: 20 January 2020. (2020). https://www.who.int/docs/default-source/coronaviruse/situation-reports/20200121-sitrep-1-2019-ncov.pdf [Accessed on April, 19, 2020].

[40] European Centre for Disease Prevention and Control, Novel coronavirus disease 2019 (COVID-19) pandemic: increased transmission in the EU/EEA and the UK - sixth update - 12 March 2020, Stockholm: ECDC, (2020).

[41] A. Widel-Smith, C.J. Chiew and V.L. Lee, Can we conatain the COVID-19 outbreak with the same measures as for SARS? The Lancet Infectioous Diseases (2020). doi: 10.1016/S14733099(20):30129-8.

[42] C.K. Carret, Tenquestions and four experts on corona.EMBO Mo/Med, (2020). doi: 10.15252/emmm.202012317.

[43] Y.W. Tang, J.E.M. Schmith, D.H. Persng and C.W. Strath, The laboratory diagnosis of COVID-19 infection: Current issues and challenges, Journal of Clinical Microbiology, American Society for Microbilogy (2020). doi: 10.1128/JCM.00512-20.

[44] World Organization, Maintaining a safe and adequate blood supply during the pandemic outbreak of Coronavirus disease (COVID-19): Interm guidance: Background, CC BY-NC-SA3, OIOGO, Geneva, Sweitzerland, WHO. (2020).

[45] World Health Organization, Protecting the Blood Supply During Infectious Disease Outbreaks-Guidance for National Blood Services. (2019). https://www.who.int/publications detail/protecting-the-blood-supply-duringinfectious-diseaseoutbreaks-guidance-for-nationalblood-services[Accessed on April, 19, 2020].

[46] Asia Pacific Blood Network (APBN), Rapid Brief White Paper: 2019 Novel Coronavirus (SARS-CoV-2): Expected challenges 
and risks to blood safety. (2020). https://apbnonline.com/ images/apbn\%20rapid $\% 20 \mathrm{~b}$ rief\%20white\%20paper\%202019 $\% 20$ novel\%20coronavirus\%20sars-cov-2.pdf [Accessed on April, 19, 2020].

[47] European Centre for Disease Prevention and Control, Rapid risk assessment: Outbreak of novel coronavirus disease 2019 (COVID-19): Dncreased transmission globally - fifth update. (2020). https://www.ecdc.europa.eu/sites/default/files/documents/RRA-outbreak-novel-coronavirus-disease2019increase-transmission-globally-COVID19.pdf[Accessed on April, 20, 2020].
[48] United State Food and Drug Administration, Important information for blood establishments regarding the novel coronavirus outbreak. (2020). https://www.fda.gov/vaccines-bloodbiologics/safety-availability-biologics/important-information-blood-establishments-regarding-novelcoronavirusoutbreak [Accessed on April, 19, 2020]. 